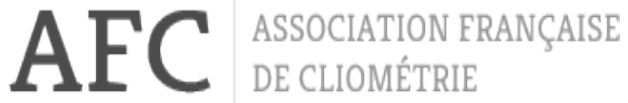

WORKING PAPERS

\section{Nr. 7, 2011}

Regional Inequality in Human Capital

Formation in Europe, 1790-1880

Ralph HIPPE, Joerg BATEN 


\title{
Regional Inequality in Human Capital Formation
}

\section{in Europe, 1790 - 1880}

\author{
Ralph Hippe $^{1}$ and Joerg Baten ${ }^{2}$
}

\begin{abstract}
Recent theoretical advances reveal the importance of human capital for long-run economic growth. However, the absence of data makes it difficult to measure human capital before 1870 at the national level, let alone at the regional level within countries. By using the age heaping method and a large, new dataset, we approximate the numeracy values in more than 570 regions in Europe between 1790 and 1880. The results indicate a significant gap in numeracy levels between advanced West and Central European countries and the rest of Europe. Nevertheless, differences in basic numeracy between and within countries became smaller over the $19^{\text {th }}$ century, as the periphery solved its basic numeracy problem.
\end{abstract}

Keywords: Human Capital, Numeracy, Regional Development, Inequality, Europe

JEL codes: N33, N93, O18

Acknowledgements: We thank Robert C. Allen, Sascha O. Becker, Ron Boschma, Elise S. Brezis, Claude Diebolt, Giovanni Federico, Jane Humphries, Pedro Lains, Jaime Reis, Jacob Weisdorf, Ludger Woessmann and participants of the GLOBALEURONET Summer School 2010, of the DIMETIC Summer School 2010 in Pécs, of the International Human Capital Workshop 2010 in Tuebingen, seminar participants at the University of Oxford 2011, participants of Iberomètrics V 2011 and of Augustin Cournot Doctoral Days 2011 for helpful comments.

\footnotetext{
${ }^{1}$ University of Tuebingen and University of Strasbourg, ralph.hippe@uni-tuebingen.de

${ }^{2}$ University of Tuebingen and CESifo, joerg.baten@uni-tuebingen.de
} 


\section{Introduction}

Human capital is one of the most important determinants of economic growth, particularly during the transition from Malthusian stagnation to modern growth, as highlighted by Unified Growth Theory (Galor 2005, Galor and Moav 2002, Galor and Weil 2000). Already, the first endogenous growth models in the 1980s revealed its importance (Romer 1990, Lucas 1988). However, were regional inequalities in education aggravated or smoothened within countries during the $19^{\text {th }}$ century? Answering such a question using quantitative techniques has turned out to be difficult, even though doing so is important in order to understand the importance of human capital in the long run. Because human capital cannot be measured directly, proxies such as literacy, schooling or numeracy are commonly employed. Thus, estimations of human capital levels in Europe have been possible for some countries at the national level. However, data are still missing at the regional level in many cases, particularly for the first half of the $19^{\text {th }}$ century. Moreover, there is no study known to us that is able to capture regional inequalities in human capital for the whole of Europe to that time. This paper is a contribution toward filling this gap in the literature. It explores human capital levels for the first time in the regions of Europe during the period between 1790 and 1880, by employing the age heaping method to calculate numeracy values. This method has increasingly been used in the recent literature on long-run human capital formation (e.g., Crayen and Baten 2010, A'Hearn et al. 2009). As a result of our large, new data set, we are able to cover nearly all of the countries of Europe, totalling more than 570 regions ranging from Portugal to Russia and from Norway to Italy.

The paper is structured as follows: first, it outlines some important aspects of the existing evidence on the development of economic performance and of human capital in Europe in the $19^{\text {th }}$ century. Then, the age heaping method is presented. Subsequently, the characteristics of the data and the spatial methodology are presented. Our data stem from 
population censuses that were taken mainly in the $19^{\text {th }}$ century. The historical regions are coded into today's current regions. For this reason, we employ the NUTS classification developed by the European Union. Descriptive, cartographic and statistical results on mean numeracy values follow in the next section. We analyse numeracy first on the national and then on the regional level. Based on these results, we compute regional inequalities in numeracy. Regional inequality within a country is measured by the coefficient of variation, thus allowing comparison across all European countries. A final conclusion summarises the results of the paper.

\section{Economic differences between European countries in the $19^{\text {th }}$ century}

How did the economies of the various European countries in the $19^{\text {th }}$ century develop in comparison to each other? O'Rourke and Williamson (1997) state that, during the second part of the $19^{\text {th }}$ century, economic performance was converging between the 'core' and the 'periphery' countries in Europe. The term 'core' describes the geographic location of countries in Europe and their industrial output at the same time. In this context, the core countries include Belgium, France, Germany, Great Britain, the Netherlands and Switzerland, whereas the periphery countries include Finland, Ireland, Italy and Spain. Taking GDP per capita as an example, the authors conclude that periphery countries had values of only about a third of the core countries' values in 1870. Even though the periphery advanced until 1914, the following decades revealed important growth differences within this group. In particular, whereas the Scandinavian countries caught up to the core, countries in Southern Europe fell behind it. Slow growth for the Southern European countries was found by Good and Ma (1999). In contrast, countries in Central and Eastern Europe grew at much higher rates, resulting in a pattern of overall convergence. Ivanov and Tooze (2007) are less optimistic for the case of the Balkans because their data suggest that GNP per capita stagnated in Bulgaria 
throughout the period. Similarly, Foreman-Peck and Lains (2000) argue that countries such as Serbia and Greece were not able to generate high growth rates.

How can we explain these differences in economic growth? For example, Tortella (1994) describes the case of the 'Latin' countries in detail, i.e., Italy, Spain and Portugal. These countries share common cultural and geographic attributes, which could partially explain their similar economic retardation up to that time. He argues that agricultural conditions were worse than in the northern countries of Europe due to the adverse characteristics of the climate and the soil, which decreased agricultural productivity and the possibilities of technological progress. Long-lasting budget deficits of the governments and similar, detrimental land tenure systems were other drawbacks to these countries' efforts to catch up economically. Moreover, the education of the population, as approximated by literacy rates, was on a much lower level than in Great Britain, France or Belgium. Basic education, as measured by literacy (and, we may add, numeracy), could have an impact on the individual in several ways: on the one hand, workers may become more productive, and on the other hand, they may be able to adapt faster to changing environments and new challenges. Finally, they acquire new skills and learn more quickly. Thus, the lack of education may be a factor that limited the economic performance of these countries.

\section{Human capital and education in $19^{\text {th }}$ century Europe}

In line with this reasoning, Sandberg (1979) showed that education was an important factor for long-run economic development in Europe. Support for the argument that education mattered for economic growth has been established for a range of countries, including Prussia and Italy (e.g., Becker et al. 2009, Zamagni 1978). Nevertheless, the exact relationship between human capital and growth in the $19^{\text {th }}$ century is still not very clear. ${ }^{3}$

\footnotetext{
${ }^{3}$ As an example, O’Rourke and Williamson (1997) argue that, for the period between 1870 and 1913, forces of
} 
One central limiting factor in this analysis is the availability of data on human capital. Unfortunately, evidence on regional development and regional inequality of human capital in Europe before the $20^{\text {th }}$ century is still rather scarce, particularly for the time before 1870 . Human capital cannot be measured directly. Instead, it has to be approximated by related, quantifiable variables. Examples of such proxies employed for modern times include literacy, numeracy, enrolment rates, years of schooling or books per capita (e.g., A'Hearn et al. 2009, Baten and van Zanden 2008, Benavot and Riddle 1988).

In addition to these indicators, the beginning of compulsory schooling had a strong effect on subsequent educational levels. A minimum level of the education of soldiers and ordinary citizens was supposed to ameliorate the military and economic position of the country (Brint 2006). This reason was one of the reasons why more and more countries constructed mass education systems during the $19^{\text {th }}$ century. These systems replaced, integrated or partly expanded the more informal private or religious institutions that had existed until then (Soysal and Strang 1989).

Religious institutions had played a major role in providing and thus enforcing specialised instruction for centuries, particularly in Protestant countries (Vincent 2010). Consequently, alliances between the state and the national church facilitated nationwide education in some countries. In others, however, schooling laws even led to conflict, as both the state and religious organisations struggled to control schooling. For instance, the Catholic Church fought in France against the state in order to teach conservative values, whereas the state preferred to promote Republican ideas. Hence, compulsory schooling was enacted relatively recently and in a successful way (by the Ferry law in 1882). As a consequence, many different religious and societal groups tried to inhibit the development of a unified educational system in Great Britain (Soysal and Strang 1989). Furthermore, formal education stressed the individual's educational achievement and socialisation. Weber (1958) stated that these attributes are similar to the reasoning given by Protestants of having a direct link to God. 
As an alternative to his famous Protestant working ethic, Becker and Woessmann (2009) argue that Protestantism encouraged reading the Bible, so Protestants became more literate than other religious groups. This generated a more educated population which could also use these skills for economic activities. Finally, this practise spurred economic development in these countries. In any case, national Protestant churches generally supported mass schooling, as they did in Prussia, whereas the Catholic Church was often opposed to it, e.g., in France.

Consequently, the introduction of compulsory schooling varied enormously in the European countries. Prussia, Sweden and Scotland were the pioneers in introducing compulsory schooling. Denmark (1814), Greece (1834) and Spain (1838) were the first to follow in the $19^{\text {th }}$ century, whereas other Western European countries, such as Belgium (1914) and the Netherlands (1900), were very late in this pursuit. ${ }^{4}$

However, merely passing schooling laws and the reality of schooling have often been two different matters (Flora 1975). For instance, states such as Greece, Portugal and Spain were eager to achieve mass education, but their influence at the local and the societal level was often too weak to achieve this goal. Other, additional methodological concerns arise as well, because compulsory schooling laws required, in part, merely erecting school buildings. This, however, is not always equivalent to teaching pupils on a compulsory basis. For these reasons, compulsory schooling laws are not an appropriate means to measure time differences in human capital development, as early schooling laws did not ensure higher enrolment rates in later decades and centuries (Adick 2003, Vincent 2000). For instance, Prussia's initial lead in schooling laws in the $18^{\text {th }}$ century did not result in higher enrolment rates at the end of the $19^{\text {th }}$ century than in countries that had not had such laws passed until then (Schneider 1982).

In addition, most other methods are not able to estimate human capital levels before the second part of the $19^{\text {th }}$ century. For instance, school enrolment data is generally rather

\footnotetext{
${ }^{4}$ These dates refer to the years when the first important general schooling laws were passed. These laws aimed at enforcing the attendance of all children until they reached some specific age.
} 
scarce. ${ }^{5}$ To obtain literacy rates, signature rates are used in a range of studies (e.g., Reis 2005, Mitch 1993, Schofield 1981). The potential disadvantages of this method are openly acknowledged by their applicants. For instance, it is not always possible to discern if the person himself signed a marriage contract, nor is it always clear what importance has to be attributed to the responsible priest in this context. Additionally, this indicator is not always available in order to compare the regions of Europe on a larger scale.

By contrast, the 'age heaping' strategy allows one to go beyond most of the limitations already mentioned. Thus, A'Hearn et al. (2009) trace numeracy levels for 16 European countries between 1350 and 1840 . They observe a striking discrepancy between numeracy in Western Europe (e.g., France, UK, the Netherlands) and Eastern Europe. High numeracy levels were already found for the Western European and Scandinavian countries in the $17^{\text {th }}$ and $18^{\text {th }}$ centuries. Central Europe generally comes close to Western European numeracy levels, whereas Eastern Europe stays far behind. The differences are greatest at the beginning of the data for Eastern Europe in the $17^{\text {th }}$ century. Similar results were established in an even more recent paper on the development of global numeracy (Crayen and Baten 2010).

\section{Deriving age heaping from historical censuses}

The age heaping method investigates the numeric skills of a population and has been used in a multitude of recent studies (e.g., A’Hearn et al. 2009, Manzel and Baten 2009, de Moor and van Zanden 2008). It uses the declarations made in census records or other documents, as is also the case in this study. Census taking itself has a very long history and, therefore, the age heaping technique can be used for long-run estimations of human capital. The ancient Egyptians, Persians, Hebrews, Greeks, Romans and Japanese had already conducted censuses. The motivation for these historical censuses was 'limited to matters of wealth, military campaigns, or defense' (Goyer and Draaijer 1992, p. 6). During the Middle Ages, censuses

\footnotetext{
${ }^{5}$ A notable exception is Prussia (see e.g. Becker and Woessmann 2009).
} 
and the counting of people were rather rare. A well-known and, for its time, very detailed example of a census was the Domesday Book of 1085, which counted the English population for tax purposes. Moreover, censuses on the city level were reported in Europe during the $15^{\text {th }}$ and $16^{\text {th }}$ century. As trade between cities and countries increased during the Renaissance, not only were goods counted increasingly more often, but the rulers also became interested in knowing the number of their subordinates. This went hand in hand with a change in the perspective of the 'value' of the people. Individuals were no longer regarded only as taxpayers or soldiers but also as economic assets by the state authorities. The importance of this manpower further increased during the industrial revolution.

The first prototypes of what is commonly called the modern census include those of New France (Québec) in 1666 and of Iceland in 1703. On a much larger scale, Sweden undertook its first census in 1749 (Goyer and Draaijer 1992). Modern times witnessed a great proliferation of census taking, beginning on a decennial basis in the United States (1790) and England (1801) and quinquennially in countries such as France (1801). On the international level, states exchanged their views on census taking increasingly more often, culminating in the International Statistical Congresses being held. The first of these congresses took place in Brussels (1853). They made recommendations and the first principal requirements for census taking. Nevertheless, they did not feature any structural organisation or membership, which changed with the foundation of the International Statistical Institute (ISI) in 1885. To facilitate the access to census data, the ISI supported the international publication of census results (Sahai 1988).

The wealth of this census material generated in the $19^{\text {th }}$ century allows us to construct estimates of human capital for the whole of Europe. By using the age heaping method, we can take advantage of the fact that one of the basic questions posed to individuals by a census taker was their age. However, parts of a population did not know their exact age in Europe at 
that time. ${ }^{6}$ Consequently, individuals rounded their ages by ' 0 ' and ' 5 '. For example, a 47 year old man would have erroneously told the census taker that he was 50 years old. Census records therefore depict a typical heaping of these ages. The census of Bulgaria serves as an example (Figure 1).

Factors other than human capital could also be attributed to this phenomenon. For instance, intentionally false age declarations, which were made in order to avoid the negative consequences of being part of a particular age group, and bad state administrations played some role. Also, the awareness of one's age in early adulthood is often increased because of events such as marriage. However, other studies have already demonstrated that educational investments play the most important role in age heaping, when they are included in multiple regressions, and that other institutional factors have no systematic impact (Crayen and Baten 2010).

Moreover, age heaping is highly correlated with literacy indicators, which has already been demonstrated by previous research (e.g., Crayen and Baten 2010). In order to make an analysis with regional data, we plot age heaping against literacy data. The literacy rate is defined here as the share of individuals in the population that is able to read and write. We use the smallest available administrative unit. With respect to our data, this unit is most often the county level. For example, we find a high correlation between literacy and numeracy in Ireland in the census of 1841 (Figure 2). We are also able to plot the data separately, age group by age group. The differences between one age group and another are thus shared by both indicators. Another case is Serbia in 1895 (Figure 3). However, literacy data is not distinguishable by age in the case of Serbia. For this reason, we look at the relationship between age heaping for all ages between 23 and 72 years and the overall literacy data. We obtain a similar picture with corresponding results.

\footnotetext{
${ }^{6}$ Yet age heaping is still observable in current censuses in parts of Asia and Africa.
} 
One advantage of age heaping is that, in contrast to literacy rates, the indicator measuring age heaping is calculated using the data on the age distribution in the population statistics. Therefore, it is not explicitly given in the statistics. As a consequence, it is less prone to voluntary manipulation by state authorities. These authorities may have had, in some cases, an interest in governing a population characterised by high literacy levels in order to hush up the backwardness of their education and their economic system. Nevertheless, statisticians may be tempted to smooth the peaks in the age distributions to arrive at the real age structure. ${ }^{7}$ In addition to factors such as costs and time consumption being used in establishing detailed statistics for individual age years, this may be another reason for why a range of census publications does not contain tables on individual ages but on age groups.

All in all, age heaping allows for the measurement of the basic numeric skills of a population in general and an analysis of the development of human capital in most European regions in a long-term perspective in particular. In this paper, it is calculated by using a transformed Whipple Index, the ABCC Index. The original Whipple Index (WI) relates the number of age observations on ' 0 ' and ' 5 ' to the total of observations. It is defined as follows:

$$
W I=\frac{\sum_{i=5}^{14} n_{5 i}}{\frac{1}{5} \sum_{i=23}^{72} n_{i}} \times 100,
$$

where $i$ stands for the years of age and $n$ stands for the number of observations. Values range between 100 and $500^{8}$, where a value of 100 means that age heaping is not present and 500 means that all age observations are in multiples of five. Because this range is not very intuitive, A'Hearn et al. (2009) proposed a new index, the ABCC Index. ${ }^{9}$ It is a linear transformation of the Whipple Index, as can be seen by the following formula:

\footnotetext{
${ }^{7}$ Yet if they did so, then age heaping would normally be equal to zero, which can mostly be identified.

${ }^{8}$ Values below 100 are also possible but are normally found in samples with a low number of observations.

${ }^{9}$ The abbreviation 'ABCC' refers to the first letter of the authors' names (A'Hearn, Baten, Crayen) and Gregory Clark.
} 


$$
A B C C=\left(1-\frac{W I-100}{400}\right) \times 100 .
$$

The ABCC Index has the advantage that it is more accessible and more comprehensive than the Whipple Index. Values are from 0 to 100 , where 100 is the maximum numeracy level and 0 the lowest. Consequently, the range of this index is identical to the ranges of other conventional indices, which makes comparisons easier. Therefore, the following analyses are performed using the ABCC Index.

Additionally, as in previous studies, we limit our age data to the years above 23 and below 72 . Under the threshold of 23 , it is possible that individuals did not themselves declare their age and their parents did it for them. Moreover, ages above 72 may be prone to a selection bias because only those who are still alive can be counted. Because the individuals benefiting from a long life represent only a part of the total, it is advisable to exclude them from the analysis. Consequently, the numeracy values can be calculated for five subsequent birth decades. Moreover, as proposed by Crayen and Baten (2010), we have adjusted the age group ranging from 23 to 32 years because this age group heaps systematically less than the other ones.

\section{Data}

To compare the development of numeracy in most European regions, a large, new dataset has been assembled from many individual sources, typically census records. This has the advantage that official documents are used. These are often well documented with respect to the methods employed during census taking. Possible measurement problems can thus be avoided or corrected. Additionally, the data employed are total population censuses, meaning that we have included all individuals of each country between the ages of 23 and 72 years. ${ }^{10}$

\footnotetext{
${ }^{10}$ Except for the census of Greece in 1907, where it is only possible to include age data from people between the ages of 23 and 32 because data for individual years is only available up to the age of 34 .
} 
This makes the data much more representative than alternative measures which only use selected groups, such as married people or military recruits. Altogether, the database includes samples covering over 570 regions in 39 European countries (in today's borders) for the time period between 1790 and 1880. An overview of the countries covered in this study and the corresponding time frame is given in Table 1. Clearly, not all the data refer to the same time period. The reason for this is that the censuses included were taken in different years and decades. Whereas the earliest data are from Ireland, France, the Netherlands, Belgium and Denmark, the most recent data come from Portugal and Cyprus. ${ }^{11}$ Still, the detailed geographical coverage allows analyses of the regional distribution of human capital, which has not been possible until now. Moreover, future research will enable us to fill in some of the missing data.

An issue that has to be taken into account when studying data from different census years is border changes. Because national borders changed during the $19^{\text {th }}$ century in some cases, due to wars or other events (e.g., the French region Alsace was annexed by the German Empire in 1871), it is possible that a region is not listed in any available census or is included in censuses of two different countries. In the former case, we had to limit ourselves to these data restrictions, and in the latter case, we interpolated the corresponding regional values or opted for the most appropriate one for intra-country comparisons.

For the age heaping method to be employed, data for individual ages are required. Unfortunately, some countries preferred not to ask the individuals of the population their exact age. In its place, these had to declare their age in certain age groups ( $20-25$ years or 20 - 30 years, etc.), for example, as in some German states prior to unification. In these cases, it is not possible to use the age heaping method. In contrast, due to space requirements or other reasons, countries sometimes indicated aggregated age groups in their official census publications instead of individual years. This is true for some available publications, e.g., for

\footnotetext{
${ }^{11}$ The exact sources are documented in the appendix.
} 
Greece or Malta in the period of our study. Unfortunately, original census lists have not always survived to allow the compilation of individual, disaggregated data, which could otherwise be used to obtain the required individual ages.

Finally, Sweden is a special case, due to its tradition of using birth registers and similar documents to construct population data, instead of questioning the population itself in a real census. This means that age data were not derived by the responses of individuals. For this reason, we cannot use these data. The same case can be made for Finland, which inherited the same counting strategy from its time under Swedish rule. However, population registers were not always used. It was clearly the preferred method to estimate data on the whole population. ${ }^{12}$ Consequently, the evidence does not yet cover Sweden and Finland. ${ }^{13}$ However, it is still possible that further research might allow us to collect data for these countries and from sources not yet available to us. Still, we were able to include all other countries of Europe, except small area states, such as Malta or Vatican City, in this study. ${ }^{14}$ This yields a geographical coverage previously unachieved in the literature.

At the regional level, it is important to define a 'region' first. Our territorial definition of a region corresponds to the current NUTS classification employed by the European Union. The 'Nomenclature des Unités Territoriales Statistiques' (NUTS, Nomenclature of Territorial Units for Statistics) was adopted in 1988 to produce regional statistics within the European Union. NUTS covers all the member states of the $\mathrm{EU}^{15}$, the EFTA countries ${ }^{16}$ and Candidate Countries ${ }^{17}$ whose aim is to join the EU. It is obvious that territorial units in the European

\footnotetext{
${ }^{12}$ In contrast, data on the population of the major cities were collected by census takers, as in other European countries. Thus, these data are also characterised by age heaping. Nevertheless, because all our other data are homogeneous in the sense that they always cover the whole population, and because the exact relationship between the urban and rural population is not yet sufficiently clear, we decided not to include these data in the framework of this study.

${ }^{13}$ Nevertheless, the Finnish data already indicate that numeracy should be at a high level in this country.

${ }^{14}$ For Romania, we only have data for the parts of the Hungarian Kingdom.

${ }^{15}$ These are Belgium, Bulgaria, Czech Republic, Denmark, Germany, Ireland, Greece, Spain, France, Italy, Cyprus, Latvia, Lithuania, Luxembourg, Hungary, Malta, Netherlands, Austria, Poland, Portugal, Romania, Slovenia, Slovakia, Finland, Sweden and the United Kingdom.

${ }^{16}$ Lichtenstein, Norway and Switzerland.

${ }^{17}$ Montenegro, Croatia, FYROM, Turkey and Iceland.
} 
countries in the $19^{\text {th }}$ century were, in many cases, quite different from today. ${ }^{18}$ In particular, two World Wars changed the territories of many existing countries, and new countries were formed by dividing old Empires (in particular, Austria-Hungary). In addition, World War II had major impacts on the (ethnic and linguistic) composition of the population of many regions and administrative reforms carried out by the states changed the territorial characteristics of a multitude of regions.

By contrast, European population density patterns have stayed more or less the same in Europe for more than a hundred years (Martí-Henneberg 2005). The author measured a high correlation of 0.83 by comparing the population density patterns in Europe in the years 1870 and 2000. Thus, many highly populated areas have attracted individuals for decades and centuries. Based on this result, current population density patterns may correspond roughly to those in the second half of the $19^{\text {th }}$ century and, in many cases, even before then. With this in mind, it is clear that the use of NUTS territorial categories does allow for a rough estimation of actual regional human capital values.

In addition, using the administrative units of the $19^{\text {th }}$ century would not be currently possible, as there is no data set available to us with boundaries at such a detailed subnational level for the whole of Europe. However, employing current NUTS regions has some additional advantages: first, it allows us to make the data more comparable over time because we look at constant and fixed boundaries. Second, it gives us the ability to compare the data from the $19^{\text {th }}$ century with more recent data, in future research.

Furthermore, we take into account the changing national boundaries by attributing today's NUTS regions to national (or, in part, ethnic) boundaries of the $19^{\text {th }}$ century, where necessary. For instance, Poland is defined by its borders within the Russian Empire during the $19^{\text {th }}$ century. For this reason, some current Polish NUTS regions are treated as German

\footnotetext{
${ }^{18}$ Notable exceptions include Spain and France.
} 
regions, as they formed part of the German Empire when the census was taken. We proceed similarly with other regions of this kind. ${ }^{19}$

Consequently, we choose to adapt the territorial administrative divisions of the $19^{\text {th }}$ century as closely as possible to those of the current NUTS classification, even though this inevitably leads to some geographical inaccuracies. Thus, data between 1790 and 1880 are available for some countries at the NUTS3 level and others are available at the NUTS2 level. To harmonise territorial sizes, we opted for the smaller NUTS2 level for all regions in our further data analysis. ${ }^{20}$ Unfortunately, the NUTS classification is only available for the member states of the European Union and Candidate Countries, as well as EFTA members. For this reason, a somewhat corresponding classification had to be found for other European countries. This concerned, in particular, countries located in East and South-East Europe, such as Russia, Ukraine, Belarus and Serbia. In these cases, we take the current territorial administrative division of these countries. Table 2 gives more details on the countries and the regions contained in our data set. For many countries, we have data for the lowest regional classification units, i.e., NUTS3. ${ }^{21}$ Still, this does not necessarily mean that data would not be available for even smaller units. In the case of Austria, the 33 NUTS3 regions have been formed from more than 70 original counties ('Bezirks-Hauptmannschaften') in the Austrian Empire located in today's Austria. The collected data are also similarly detailed for other countries, such as the other parts of the Austrian-Hungarian Empire (NUTS3) and the United Kingdom and Italy (NUTS2). Clearly, this wealth of regional data reduces possible biases arising from the use of current administrative borders.

\footnotetext{
${ }^{19}$ As a caveat, we should note that we cannot directly compare the historical numeracy and today's numeracy level due to population movements, but this comparison is the purpose of this study.

${ }^{20}$ For mapping purposes, we decided to use the smallest available territorial unit to highlight the regional differences as clearly as possible.

${ }^{21}$ Or similarly small units for countries not included in the NUTS classification.
} 


\section{The development of human capital in European countries}

To obtain a general idea of the distribution of ABCC values for Europe, we have calculated the ABCCs for all European countries between 1790 and 1880 in our data set. The results are depicted in Figure 4. Its sole purpose is to show general tendencies and, hence, country labels have been omitted. As our first conclusion, we state that $\mathrm{ABCC}$ values differ importantly throughout Europe. Numeracy ranges between 25 and 100 ABCC points.

In our second step, we have divided the European countries into several macroregions, due to the large number of countries under study. These are the core industrial European countries $^{22}$, Austria-Hungary, the Western European periphery countries, the East European countries and the South-East European countries. ${ }^{23}$ The attribution to one macroregion was effected mainly by reason of geographical location and economic output. Core Europe is constituted by countries such as France, Germany and the United Kingdom. The case for the macroregion Austria-Hungary is self-evident, as it is made up of the regions of the dual monarchy. The Western periphery consists of countries from Scandinavia (Denmark, Iceland, Norway) plus Ireland, Italy, Spain and Portugal. The regions of the Russian Empire have been attributed to Eastern Europe and, in part, South-East Europe (Armenia, Azerbaijan, Georgia), which also comprises countries from the Balkans. By employing this classification, all macroregions also comprise a similar number of countries. The details on the development of ABCCs in the various geographical macroregions can be found in Figure 5 to Figure 9. Because the focus here is on the differences within the macroregions and on a clear visualisation of the $\mathrm{ABCC}$ trends, the scale of the $\mathrm{ABCC}$ mean values is very different in each

\footnotetext{
${ }^{22}$ Our classification of the core countries corresponds to the one employed by O'Rourke and Williamson (1997), except that it has been extended by also including Luxembourg.

${ }^{23}$ Core Europe is comprised of Belgium, Switzerland, Germany, France, Luxembourg, Netherlands and the United Kingodom, Austria-Hungary of Austria, Czech Republic, Croatia, Hungary, Romania, Slovenia and Slovakia, the Western Periphery of Denmark, Spain, Ireland, Iceland, Italy, Norway and Portugal, Eastern Europe of Belarus, Lithuania, Latvia, Estonia, Moldova, Poland, Russia and Ukraine and South-East Europe of Albania, Armenia, Azerbaijan, Bosnia-Hercegovina, Bulgaria, Cyprus, Georgia, Greece, Macedonia and Serbia.
} 
figure. This always has to be taken into account when interpreting the development of ABCC values. But, it makes the interpretation of trends within the macroregions easier.

Several results can be highlighted: countries from the European 'core' are already characterised by high $\mathrm{ABCC}$ values at the beginning of the $19^{\text {th }}$ century (Figure 5). The differences between these countries are minor, even though France catches up to Belgium and to the Netherlands between 1790 and 1820.

The regions of the Austro-Hungarian Empire are more diverse (Figure 6). For Cisleithania (today mainly constituted by Austria, the Czech Republic and Slovenia), the ABCC values are high and similar to those in the core. The picture is different for Transleithania (today mainly constituted by Hungary, Slovakia, parts of Romania and Croatia $^{24}$ ); Croatia enjoyed the highest ABCC values initially, followed by Hungary, Slovakia and today's Romanian provinces. Notably, this order stays rather constant over time, except that Romania overtook Slovakia later in the period. The Croatian and Romanian provinces follow similar patterns; this is also true for Hungary and Slovakia. All parts of Transleithania are converging over the time span covered.

Taking a closer look at the Western periphery (Figure 7), the Scandinavian countries are characterised by very high $\mathrm{ABCC}$ values. Italy, Spain and Portugal are evolving rather slowly with values at around an $\mathrm{ABCC}$ of 90. Ireland is on a much lower level than other Western European countries, but it is progressing.

Most regions of the Russian Empire form the East European countries (Figure 8). The range of $\mathrm{ABCC}$ values is very striking. It is astonishing that the Baltic States have such varied $\mathrm{ABCC}$ levels: Estonia is characterised by $\mathrm{ABCC}$ levels on the same level as in the core countries, whereas Latvia and Lithuania follow only after large intervals. Lithuania finds itself

\footnotetext{
${ }^{24}$ Today's Croatia was split between Cisleithania (mostly Dalmatia) and Transleithania (Croatia-Slavonia). Here we refer only to the part belonging to Transleithania.
} 
with Belarus at the end of the numeracy ladder. Moreover, Poland initially has an important lead over Russia and Ukraine.

Finally, South-East Europe (Figure 9) features the lowest numeracy values in our data set. The Caucasus regions (forming part of the Russian Empire) and Albania are the least numerate of all European regions. Numeracy in Bulgaria is somewhat higher and is increasing. Serbia, Bosnia-Herzegovina, Macedonia and Cyprus do better, but the earliest data is already relatively late with respect to the other countries.

All in all, we find noticeable differences in numeracy between and within the observed macroregions.

\section{Taking a closer look at the educational differences in Europe}

How can we explain these differences in human capital? A first look might be attributed to the possibilities of generating human capital: educational policies and schooling institutions. Because the Western European countries and parts of the Western Periphery have been shown to feature very high numeracy values in general, it appears more important to consider the less numerate countries, particularly in Eastern and South-Eastern Europe.

Why were the differences so large in the Russian Empire? In particular, the Baltic states appear to be anything but homogeneous. Let us consider these regions in more detail. Lithuanian education faced important restrictions under Russian rule, e.g., Lithuanian schools and publications in Lithuanian were not allowed (Giedraitiene et al. 2007). Similarly, in Belarus, education in the form of schools was mostly limited to populations in cities (Sroka 2007). Because the ABCC differences in the Baltic States are similar to the literacy rates, one may refer to Mironov (1991), who attributes these differences to religion (above all, to Protestantism in the region). The Lutheran Church played an important role in promoting literacy in Estonia (Raun 1986). In this sense, the numeracy results also reflect the heritance 
of Swedish rule in the country $(1561-1721)$. From the $17^{\text {th }}$ century onwards ${ }^{25}$, the ability to read became obligatory for everyone in the Swedish Empire, i.e., mainly today's Sweden, Finland and Estonia (Johansson 2009). This tradition of providing education may also have contributed to the high numeracy values in Estonia.

Moreover, countries formerly belonging to the Ottoman Empire do worse in terms of numeracy than most other regions. ${ }^{26}$ This particularly concerns the Balkans. ${ }^{27}$ The Ottoman education system was not well developed during this period. After the educational lead of the Islamic world in medieval times, the human capital revolution that took place in the West did not happen in the Ottoman Empire.

As an example, we can take a look at Bulgaria which, as we have seen, has one of the lowest ABCC rates in our sample. Bulgaria lost its independence in 1396 and from that time was ruled by the Ottoman Empire until its final de jure independence in $1908 .{ }^{28}$ Very few educational facilities were available until the $19^{\text {th }}$ century, and these were mostly small cell schools. This also highlights the importance of the Orthodox Church in Bulgaria and in other countries in the Balkans. It 'promoted education, which it considered an important means for upholding the Christian faith under the Ottomans' (Daskalova 1996, p. 6). Nevertheless, nothing comparable to a modern education system was established. This is also illustrated by the fact that only 142 cell schools existed in 1762 and this number grew to only 235 by 1835 (Crampton 2007). A widespread, 'nationwide' drive to foster education was created much later than in other countries. Moreover, the teaching that was available was mostly in Greek. However, the intellectual elite of Bulgaria disapproved of the increasing cultural

\footnotetext{
${ }^{25}$ Particularly important was the Church Law of 1686.

${ }^{26}$ The most important exception to this trend is the Caucasus region, which has equally little numeracy.

${ }^{27}$ In particular, this is Serbia (independence fully recognised internationally in 1878), Bosnia-Herzegovina (occupied by the Austro-Hungarian Empire in 1878 and later annexed in 1908), Montenegro (independent in 1878), Albania, Bulgaria (self-government re-established in 1878 (Principality of Bulgaria), unification with Eastern Rumelia in 1885, de jure independence in 1908), Romania (independence in 1878), Macedonia (part of Serbia in 1913) and to some extent Greece (already independent in 1830).

${ }^{28}$ The principality of Bulgaria was already de facto independent in 1878 and was unified with Eastern Rumelia in 1885 .
} 
hegemonialism by the Greeks more and more with the passage of time. They wanted to establish schools in which the teachers used their own language. The wealthy mostly sent their children abroad, preferably to Russia, Constantinople or Western Europe. Until the liberation, this amounted to about 700 Bulgarians in total (Crampton 2007). These expatriates also had a major influence on the development of the Bulgarian educational system, as they urged the advancement of the system. Thus, moving towards the use of the Bulgarian language in educational facilities and opening up new lay schools marked a new, second step in Bulgarian development. Finally, Bulgarians advanced from mutual to new class schools, the first being established in Gabrovo in 1840 .

Clearly, the struggle for the use of their own language played an important part in the development of Bulgarian education. The first textbook that was written in Bulgarian was published in 1824, but there was hitherto no standardised form of Bulgarian; only in the 1870s did a standard, written language emerge. Another factor promoting educational development came from the increasingly prosperous towns. With rising economic progress and growing financial possibilities, the town councils were the driving forces behind the improved education of the people because they felt the need for better educated workers. Furthermore, they were able to bear some of the costs connected with setting up schools and training teachers (Daskalova 1996). Still, the overall education level of the Bulgarian people remained low during the $19^{\text {th }}$ century even though it progressed continuously.

Albania provides a similar picture, as the Albanians had to fight for Albanianlanguage schools and education, which were banned by the Ottomans (Kostovicova 2005). One issue was the establishment of a written language, and another one was the determination of the type of alphabet to be used (i.e., Latin, Greek or Arabic). As a consequence, the struggle for education in Albanian marked the move towards Albanian nationalism. The way of ruling practised by the Ottomans in South-East Europe might therefore be an important factor in explaining the low educational levels obtained. 
Finally, the examples above can also highlight the difficulties and potential biases that may arise when using or approximating literacy rates as long as a written language is not clearly defined by a state, people or region. In contrast, numeracy uses the statements of numbers, which are less dependent on language formation, particularly in South-East Europe.

\section{Regional differences at the European level}

To get insight into the regional disparities between European regions, Figure 10 toFigure 17 depict the regional ABCC values between 1800 and $1870 .{ }^{29}$ Some supplementary information is revealed by the maps. For example, there is a general North-South difference in Italy: northern regions feature higher ABCC values than southern regions. This is not unexpected, as differences between the South and the North of Italy have prevailed until today. A similar tendency can be seen in France, even though there is not such a clear divide as in Italy. Nevertheless, the North of France has a lead on the South (albeit with some exceptions), a characteristic also apparent in the literacy data (Ozouf and Furet 1977).

In contrast, the reverse geographic case can be found in Norway. Here, the distant and less populated northern provinces, particularly Finnmark, are not at the same level as the southern ones. Moreover, these regions were not only far away but also sparsely populated. Schools could only be provided at great cost because pupils had to walk long distances and urban teachers were typically not willing to work there. For these reasons, schooling had already been delayed with respect to the other provinces at the end of the $18^{\text {th }}$ century (Guttormsson 1990). An analogous observation can be made for the first birth decades observed in Great Britain, where in particular, the Highlands of Scotland have lower ABCC values than the Lowlands and some parts of England. This is interesting because previous historians of education saw Scotland as a pioneer in Europe (e.g., Lockridge 1974). Still, this

\footnotetext{
${ }^{29}$ In order to discern as many regional differences as possible, the lowest available administrative classification (NUTS 3 or NUTS 2) has been selected in the cartographic representation.
} 
generally refers to the success of educational campaigns in the Scottish Lowlands. By contrast, the Highlands possessed 'a primitive economic and social structure, few schools, and poor communications' (Houston 1987, p. 60), augmented by a language barrier due to the wide diffusion of Gaelic and adverse geographical conditions. These factors also led to lower literacy attainment rates than in the Lowlands in the first part of the $19^{\text {th }}$ century. The ABCC values suggest a similar regional disparity between these regions. ${ }^{30}$

In Spain, a core-periphery pattern is discernible. The regions in southern Andalusia and north-western Galicia are characterised by low numeracy. The area in central-northern Spain is the most advanced in the country. One might initially expect north-eastern Catalonia, and particularly the industrial region of Barcelona, to be among the leading regions within Spain. However, this was not the case. Neither in numeracy nor in literacy was Barcelona leading, as can be derived from figures published by Núnez (1992).

In the Russian Empire, we highlight the case of the region around the (now) Ukrainian city of Odessa, which had higher ABCC values than its neighbouring regions throughout time. The high level of numeracy is also in line with the literacy figures, with Odessa on a similar level as the two major cities of the Russian Empire, namely, St. Petersburg and Moscow (Herlihy 1986). ${ }^{31}$ Odessa itself is located on the northwest shore of the Black Sea and featured (until today) a major seaport. Either the economic success engendered a need for trained (and also literate and numerate) workers or the remarkable numeracy of the region (especially of the Jewish minority) enabled the harbour city to grow to a commercial centre. Also, the peasants were surprisingly apt in calculating (Goodwin and Grennes 1998). Moreover, in the Polish provinces, the south-western and eventually the central provinces around Warsaw have a lead on the eastern ones.

\footnotetext{
${ }^{30}$ Nevertheless, the reasons why the Lowlands of Scotland do not generally show higher numeracy rates than many regions in England still have to be explored further.

${ }^{31}$ Odessa had higher literacy rates than St. Petersburg but lower rates than Moscow.
} 
Finally, numeracy is very high in the regions of the German Empire and the German speaking parts of Austria-Hungary. With regard to the German Empire, the regions with the lowest $\mathrm{ABCC}$ values are found in West Prussia, Upper Silesia and partly East Prussia. ${ }^{32}$

In general, throughout Europe, it appears that the most backward regions within countries, as judged by numeracy, are often found in peripheral geographic locations, which are characterised by a lack of infrastructure and less economic power. However, more research is still needed to clarify the determinants of regional human capital formation on a European scale.

\section{Inequalities of regional human capital distribution}

Based on these first cartographic impressions, can we statistically observe regional differences in the distribution of human capital within countries? To answer this question, we measure regional inequality by using the coefficient of variation $(\mathrm{CV})$. Using the $\mathrm{CV}$ has the advantages that it is a dimensionless number and that it allows comparisons between the different countries, even though they have different means. It is defined as the standard deviation of regional $\mathrm{ABCC}$ values of a country $(\sigma)$ divided by the average $\mathrm{ABCC}$ value of a country $(\mu)$, multiplied by 100 :

$$
C V=\frac{\sigma}{\mu} \times 100
$$

We proceed similarly to the description of ABCC means. ${ }^{33}$ However, we exclude those countries that had nearly solved their basic numeracy problem because the proximity to an $\mathrm{ABCC}$ value of 100 would bias the CVs. This applies to core and Scandinavian countries. Hence, we avoid potential 'bounded variable' problems. Thus, Figure 18 to Figure 21

\footnotetext{
${ }^{32}$ Still, one has to take into consideration the already high level of attained numeracy in Prussia. For this reason, the differences are not very large.

${ }^{33}$ Not all countries are included for the calculation of the ABCC means since only data on the national level is available for the smaller countries (e.g. Luxembourg, Iceland, Estonia, Cyprus) and thus regional inequalities cannot be measured.
} 
highlight the outcomes for the macroregions. As in the case of the ABCC means, the different scales have to be taken into consideration.

In general, regional variation is shrinking throughout time in most countries. Considerable differences in the CV can initially be found in Transleithania (Eastern AustriaHungary), Ireland, Italy and Spain. However, they decrease over the decades. The paths of the different countries are different and far from a linear, straight improvement in numeracy over time. Still, nationwide homogeneity is increasingly being attained within these countries. Numeracy in East European regions within their modern frontiers is still widely dispersed, but it is also diminishing. European Russia is characterised by the highest regional variation. Given the vast territory covered by this country, even when only considering its European part, this is not a very surprising result. A particular case is Serbia. Serbia already includes the region of Vojvodina ${ }^{34}$, which belonged to Austria-Hungary but was united with Serbia after World War I. Thus, it benefited from the educational infrastructure of the Kingdom of Hungary. Accordingly, this northern region is characterised by considerably higher ABCC values than the rest of Serbia. This has led to a very high coefficient of variation and it may also highlight the persistence of regional human capital patterns over time. The only country with widening regional disparities in our sample is Bulgaria. In Bulgaria, the southern regions advance much more with respect to $\mathrm{ABCC}$ values than do their northern counterparts, resulting in an increasing South-North gap. This result may also be the outcome of the different timing of independence in the North and the South. Moreover, the Northern regions could have benefited from the proximity to the Danube, a major trade route even today. Still, Bulgaria was geographically and ethnically diverse. These differences may have contributed to the overall divergence.

In summary, one can generally state that a reduction of basic numeracy differences took place within and among most European countries in the $19^{\text {th }}$ century.

\footnotetext{
${ }^{34}$ The underlying census was the first undertaken in Yugoslavia in 1921.
} 


\section{Conclusion}

This paper has examined the long-term development of human capital in more than 570 regions in Europe between 1790 and 1880. We have used the age heaping method to approximate human capital values and the NUTS classification to categorise regions according to current national borders. Even though both methods have their limitations and are prone to some possible biases, this has enabled us to estimate, for the first time, the levels of human capital for most European regions in the $19^{\text {th }}$ century and to calculate regional inequalities over time.

Due to the large number of regions and countries under study, we have divided the European countries into five macroregions: core industrial European countries, AustriaHungary, Western European periphery countries, East European countries and South-East European countries. Core Western and Central European countries enjoyed high numeracy levels throughout the period. Low and medium levels of numeracy were dominant in periphery countries, particularly in Eastern and South-Eastern Europe. However, many of these countries were solving their basic numeracy problem by the middle of the $19^{\text {th }}$ century.

Regional inequalities, as measured by the coefficient of variation, were also important in many countries. As the population of a country improves its numeric abilities, regional differences become less striking. Still, the persisting inequalities in many countries highlight the importance of our regional approach. In fact, working with data on the national level does, in part, conceal major differences within countries. For this reason, future research should focus on the human capital distribution at the regional level and on the factors explaining why some regions perform better than others. 


\section{References}

Adick, C. (2003). Globale Trends weltweiter Schulentwicklung: Empirische Befunde und theoretische Erklärungen, Zeitschrift für Erziehungswissenschaft 6 (2): 173-187

A'Hearn, B., Crayen, D. and J. Baten (2009). Quantifying Quantitative Literacy: Age Heaping and the History of Human Capital, Journal of Economic History 68 (3): 783 808

Baten, J. and J. L. van Zanden (2008). Book production and the onset of modern economic growth, Journal of Economic Growth 13 (3): 217-235

Becker, S. O. and L. Woessmann (2009). Was Weber wrong? A Human Capital History of Protestant Economic History, Quarterly Journal of Economics 124 (2): 531-596

Becker, S. O., Hornung, E. and L. Woessmann (2009). Catch Me If You Can: Education and Catch-up in the Industrial Revolution, CESifo Working Paper Nr. 2816

Benavot, A. and P. Riddle (1988). The Expansion of Primary Education, 1870-1940: Trends and Issues, Sociology of Education 61 (3): 191-210

Brint, S. G. (2006). Schools and societies, Stanford: Stanford University Press

Crampton, R. J. (2007). Bulgaria, Oxford: Oxford University Press

Crayen, D. and J. Baten (2010). Global Trends in Numeracy 1820-1949 and its Implications for Long-Run Growth, Explorations in Economic History 47: 82-99

Daskalova, K. (1996). Literacy and Reading in 19th Century Bulgaria, Washington: Donald W. Treadgold Papers

De Moor, T. and J. L. van Zanden (2008). Uit fouten kun je leren. Een kritische benadering van de mogelijkheden van 'leeftijdstapelen' voor sociaal-economisch historisch onderzoek naar ecijferdheid in het pre-industriële Vlaanderen en Nederland, Tijdschrift voor Economische en Sociale Geschiedenis 5-4, 55-86 
Flora, P. (1975). Indikatoren der Modernisierung - Ein historisches Datenhandbuch, Opladen: Westdeutscher Verlag

Foreman-Peck, J. and P. Lains (2000). European economic development. The core and the southern periphery, 1870-1910, in: Pamuk, S. and J. G. Williamson (2000). The Mediterranean response to globalization before 1950, London: Routledge

Galor, O. (2005). From Stagnation to Growth: Unified Growth Theory, In: Aghion, P. and S. N. Durlauf (eds.), Handbook of Economic Growth, Volume 1A, 171-293, Amsterdam: North Holland

Galor, O. and D. N. Weil (2000). Population, Technology and Growth: From the Malthusian Regime to the Demographic Transition, American Economic Review 90 (4): 806-828

Galor, O. and O. Moav (2002). Natural Selection and the Origin of Economic Growth, Quarterly Journal of Economics 117: 1133-1192

Good, D. F. and T. Ma (1999). The economic growth of Central and Eastern Europe in comparative perspective, 1870-1989, European Review of Economic History 2: $103-$ 137

Giedraitiene, E., Kiliuvene, D. and S. Brauckmann (2007). Lithuania, in: Hörner, W., Döbert, H., von Kopp, B. and W. Mitter (eds.), The Education Systems of Europe, Dordrecht: Springer, $451-469$

Goodwin, B. K. and T. J. Grennes (1998). Tsarist Russia and the Word Wheat Market, Explorations in Economic History 35: 405-430.

Goyer, D. S. and G. E. Draaijer (1992). The Handbook of National Population Censuses. Europe, Westport: Greenwood Press

Guttormsson, L. (1990). The Development of Popular Religious Literacy in the Seventeenth and Eighteenth Centuries, Scandinavian Journal of History 15: 7-35

Herlihy, P. (1986). Odessa: A History, 1794-1914, Cambridge: Harvard University Press 
Houston, R. (1987). The literacy campaign in Scotland, 1560-1803, in: Arnove, R. F. and H. J. Graff (eds.), National literacy campaigns historical and comparative perspectives, New York: Plenum Press

Ivanov, M. and A. Tooze (2007). Convergence or Decline on Europe's Southeastern Periphery? Agriculture, Population, and GNP in Bulgaria, 1892-1945, Journal of Economic History 67 (3): 672-704

Johansson, E. (2009). The History of Literacy in Sweden, in: Graff, H. J., Mackinnon, A., Sandin, B. and I. Winchester (ed.) (2009): Literacy in its historical contexts, Lund: Nordic Academic Press

Lockridge K. A. (1974). Literacy in Colonial New England, New York: Norton

Lucas, R. (1988). On the Mechanics of Economic Development, Journal of Monetary Economics 22 (1): 3-42.

Kostovicova, D. (2005). Kosovo: the politics of identity and space, New York: Routledge

Manzel, K. and J. Baten (2009). Gender Equality and Inequality in Numeracy: The Case of Latin America and the Caribbean, 1880-1949, Revista de Historia Económica 27 (1): $37-73$

Martí-Henneberg, J. (2005). Empirical Evidence of Regional Population Concentration in Europe, 1870-2000, Population, Space and Place 11: 269-281

Mironov, B. N. (1991). The Development of Literacy in Russia and the USSR from the Tenth to the Twentieth Centuries, History of Education Quarterly 31 (2): 229-252

Mitch, D. (1993). The Role of Human Capital in the First Industrial Revolution, In: Mokyr, J. (ed), The British Industrial Revolution: An economic perspective, Boulder: Westview Press, 267-307

Núnez, C. E. (1992). La fuente de la riqueza: educación y desarrollo económico en la Espana contemporánea, Madrid: Allianza 
O'Rourke, K. and J. Williamson (1997). Around the European Periphery: Globalization, Schooling and Growth, European Review of Economic History 1: 153-190

Raun, T. O. (1986). The Latvian and Estonian National Movements, 1860-1914, The Slavonic and East European Review 64 (1): 66-80

Reis, J. (2005). Economic Growth, Human Capital Formation and Consumption in Western Europe before 1800, In: Allen, R. C., Bengtsson, T. and M. Dribe (eds.), Living Standards in the Past, Oxford: Oxford University Press, 195-225

Romer, P. (1990). Endogenous Technological Change, Journal of Political Economy 99 (5): $71-102$

Sahai, H. (1988). What is a census?, International Journal of Mathematical Education in Science and Technology, 19: 1, 119-124

Sandberg, L. G. (1979). The case of the impoverished sophisticate: human capital and Swedish economic growth before World War I, Journal of Economic History 39: 225241

Schneider, R. (1982). Die Bildungsentwicklung in den westeuropäischen Staaten 1870-1875, Zeitschrift für Soziologie, 11: 207-226

Schofield, R. S. (1981). Dimensions of illiteracy in England 1750-1850. In: Graff, H. J. (ed.), Literacy and social development in the west: a reader, Cambridge: Cambridge University, 201-213

Soysal, Y. N. and D. Strang (1989). Construction of the first mass education systems in nineteenth-century Europe, Sociology of Education 62: 277-288

Sroka, W. (2007). Belarus, in: Hörner, W., Döbert, H., von Kopp, B. and W. Mitter (eds.), The Education Systems of Europe, Dordrecht: Springer, 85-103

Tortella, G. (1994). Patterns of economic retardation and recovery in south-western Europe in the nineteenth and twentieth centuries, Economic History Review 47: 1-21 
Weber, M. (1958). The Protestant Ethic and the Spirit of Capitalism, New York: Charles Scribner's Sons.

Zamagni, V. (1978). Istruzione e sviluppo económico. II caso italiano, 1861-1913, in: Toniolo, G. (ed.), L'economia italiana, 1861-1940, Laterza: Rome-Bari, 137-78 
Table 1 Time span of covered countries

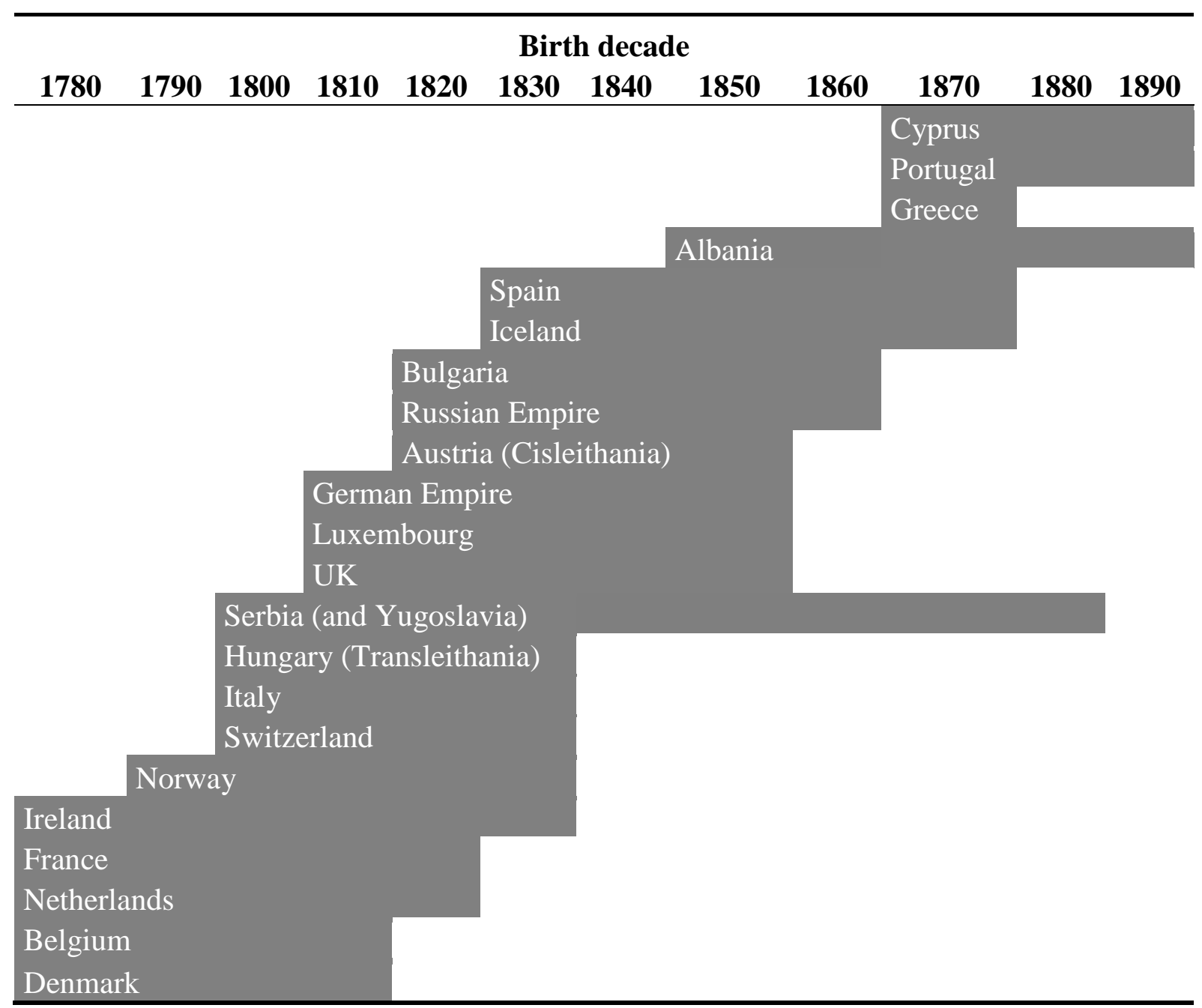


Table 2 Regional classification units ${ }^{35}$

\begin{tabular}{|c|c|c|c|c|}
\hline Code & Country & NUTS3 & NUTS2 & Non-NUTS ${ }^{36}$ \\
\hline $\mathrm{AL}$ & Albania & & & 1 \\
\hline $\mathrm{AM}$ & Armenia & & & 1 \\
\hline AT & Austria & 33 & & \\
\hline $\mathrm{AZ}$ & Azerbaijan & & & 1 \\
\hline BA & Bosnia-Herzegovina & & & 1 \\
\hline $\mathrm{BE}$ & Belgium & & 11 & \\
\hline BG & Bulgaria & & 5 & \\
\hline BY & Belarus & & & 4 \\
\hline $\mathrm{CH}$ & Switzerland & 25 & & \\
\hline $\mathrm{CY}$ & Cyprus & 1 & & \\
\hline $\mathrm{CZ}$ & Czech Rep. & 14 & & \\
\hline $\mathrm{DE}$ & Germany & & 46 & \\
\hline DK & Denmark & 10 & & \\
\hline $\mathrm{EE}$ & Estonia & & 1 & \\
\hline ES & Spain & 49 & & \\
\hline FR & France & 85 & & \\
\hline GE & Georgia & & & 1 \\
\hline GR & Greece & 24 & & \\
\hline HR & Croatia & 11 & & \\
\hline HU & Hungary & 19 & & \\
\hline IE & Ireland & & 2 & \\
\hline IS & Iceland & & 1 & \\
\hline IT & Italy & & 22 & \\
\hline LT & Lithuania & & 1 & \\
\hline LU & Luxembourg & 1 & & \\
\hline LV & Latvia & & 1 & \\
\hline MD & Moldova & & & 1 \\
\hline MK & FYROM & & & 1 \\
\hline NL & Netherlands & & 11 & \\
\hline $\mathrm{NO}$ & Norway & 19 & & \\
\hline PL & Poland & & 7 & \\
\hline PT & Portugal & & 7 & \\
\hline $\mathrm{RO}$ & Romania & 16 & & \\
\hline RS & Serbia $^{37}$ & & & 3 \\
\hline RU & Russia $^{38}$ & & & 34 \\
\hline SI & Slovenia & 11 & & \\
\hline SK & Slovakia & 7 & & \\
\hline UA & Ukraine & & & 15 \\
\hline UK & United Kingdom & & 32 & \\
\hline
\end{tabular}

\footnotetext{
${ }^{35}$ Always the lowest available administrative division is listed.

36 "Non-NUTS" refers to countries which are not in the NUTS classification.

${ }^{37}$ Includes Vojvodina, Montenegro and Kosovo.

${ }^{38}$ Only European Russia.
} 
Figure 1 Age heaping in the census of Bulgaria (1893)

Census of Bulgaria 1893

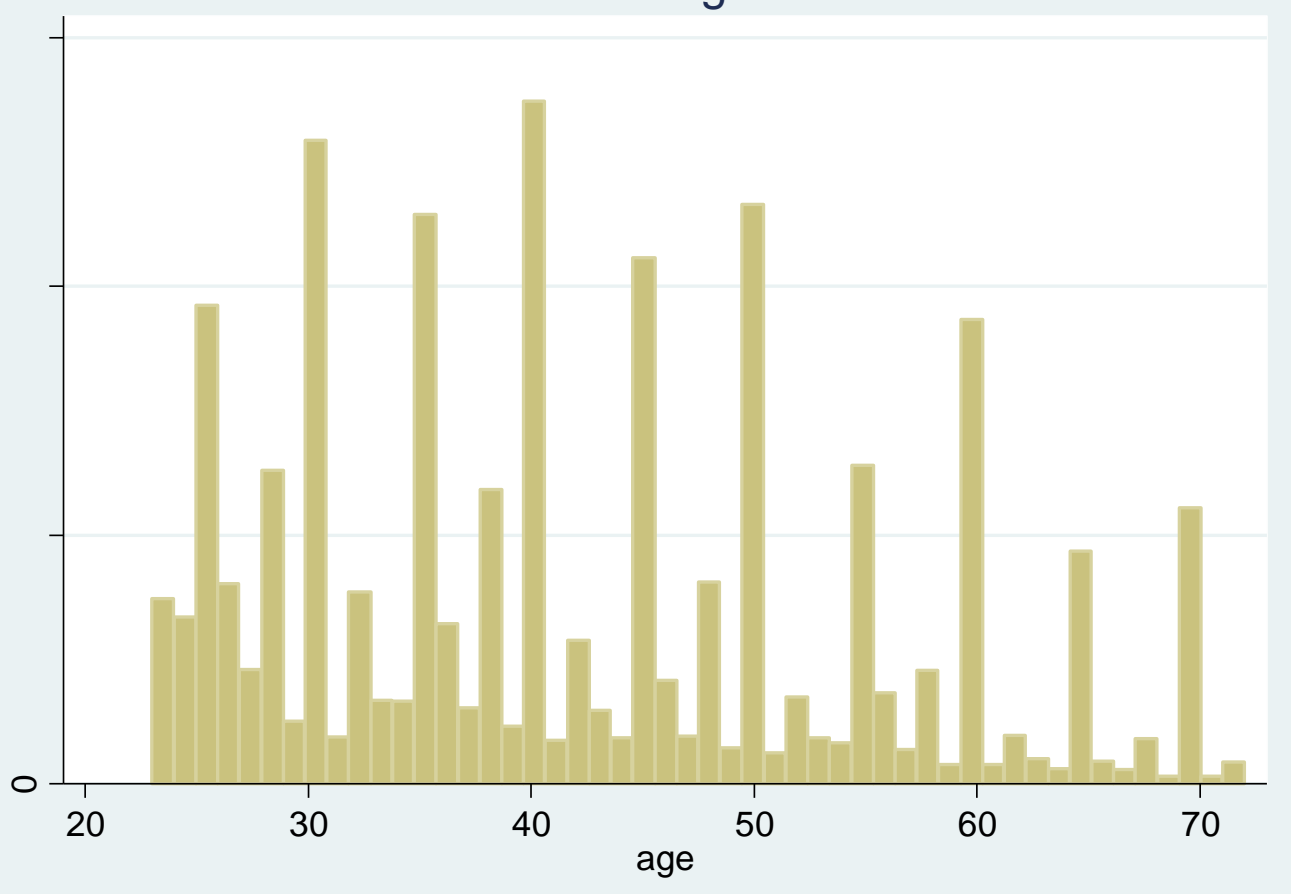


Figure 2 Regional relationship of age heaping and literacy in Ireland 1841

Regional relationship of age heaping and literacy in Ireland 1841
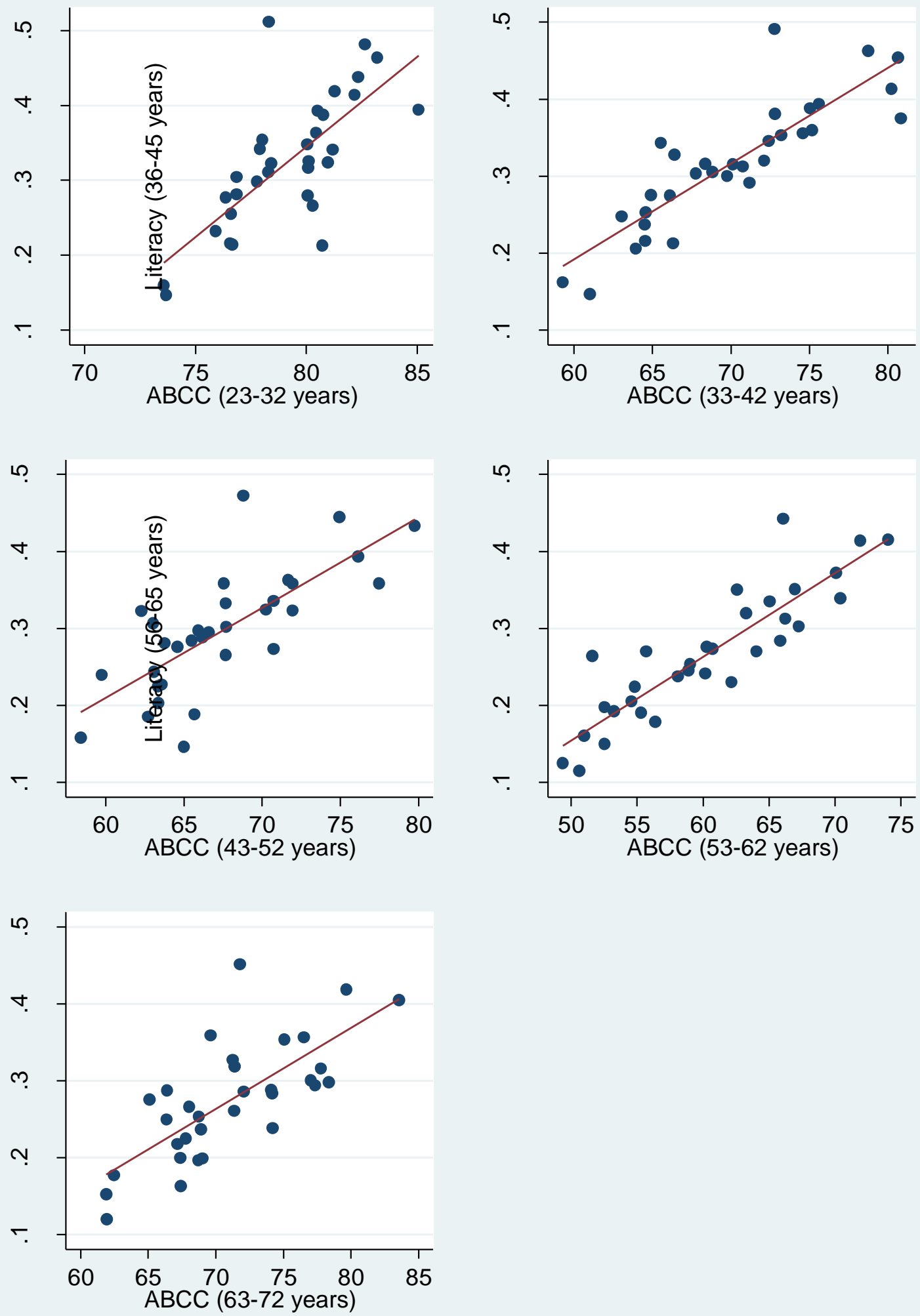

Note: Literacy is defined here as the ability to read and write. County data has been used. 
Figure 3 Relationship of age heaping and literacy in Serbia 1895

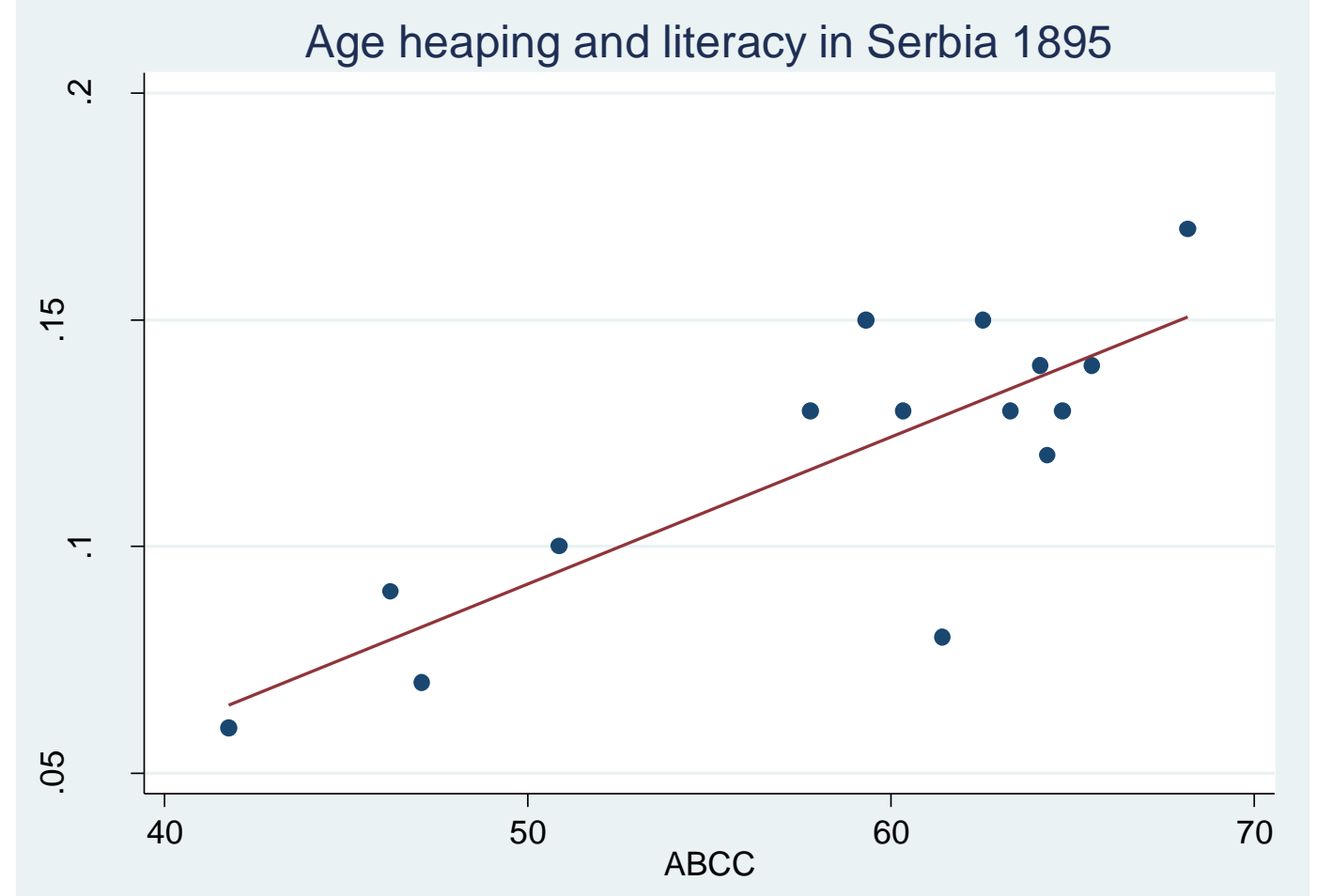

Note: Literacy refers to the ability to read and write. The ABCC is calculated by merging all individual years between 23 and 72 years old since literacy data is not available for individual age groups. 
Figure 4 Mean ABCC values for all European countries

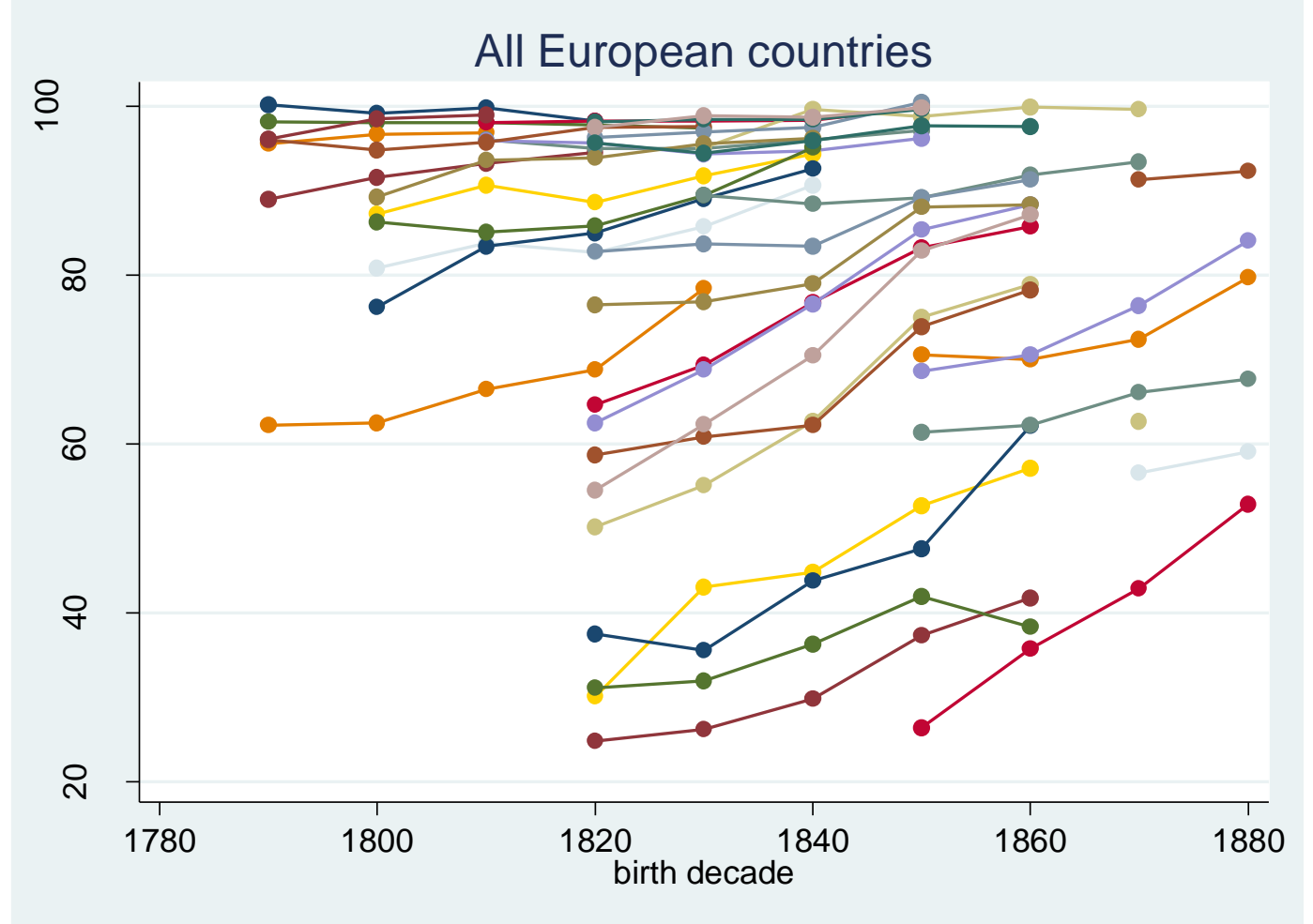

Figure 5 ABCC of Core European countries

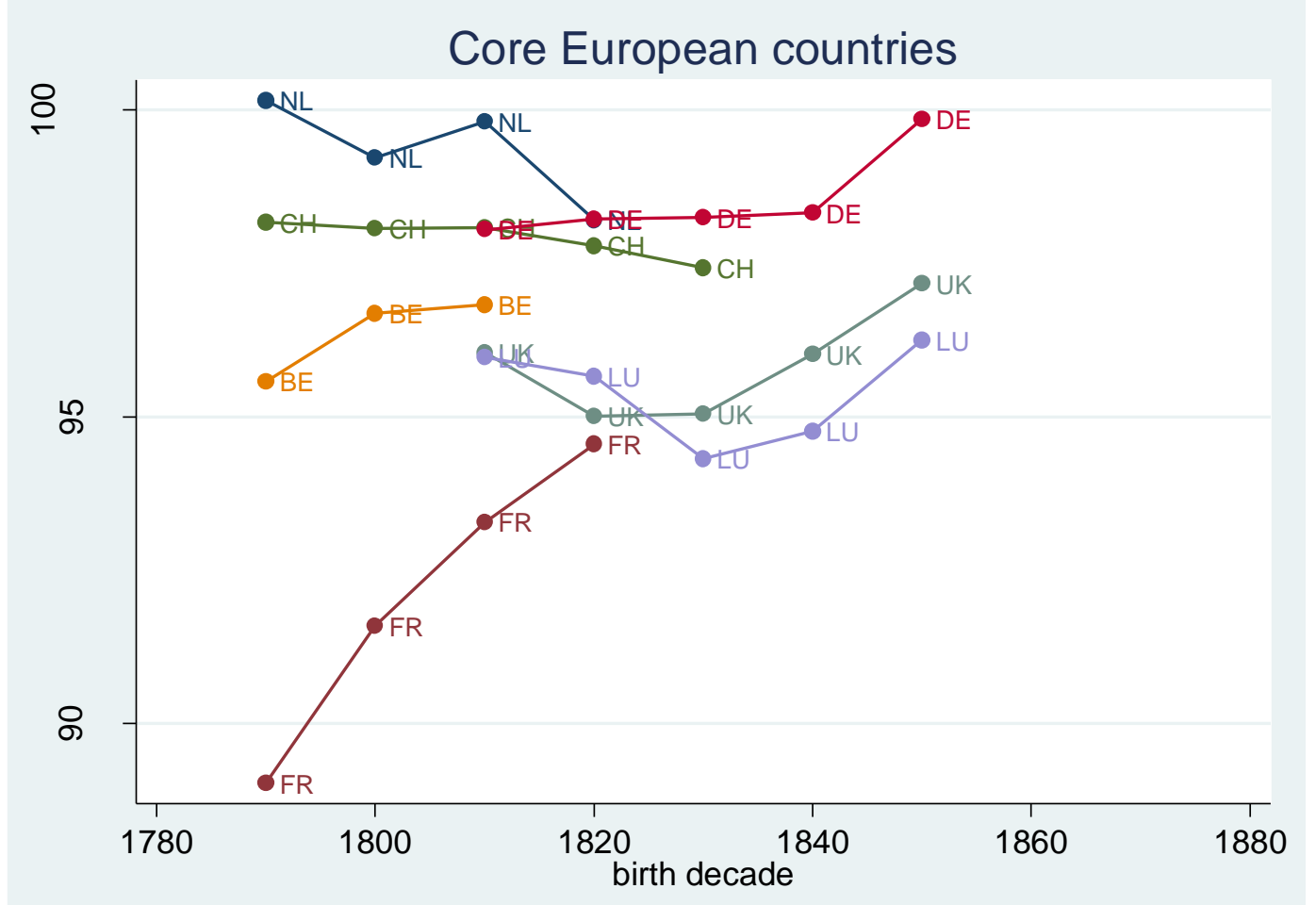


Figure 6 ABCC mean of the regions of Austria-Hungaria

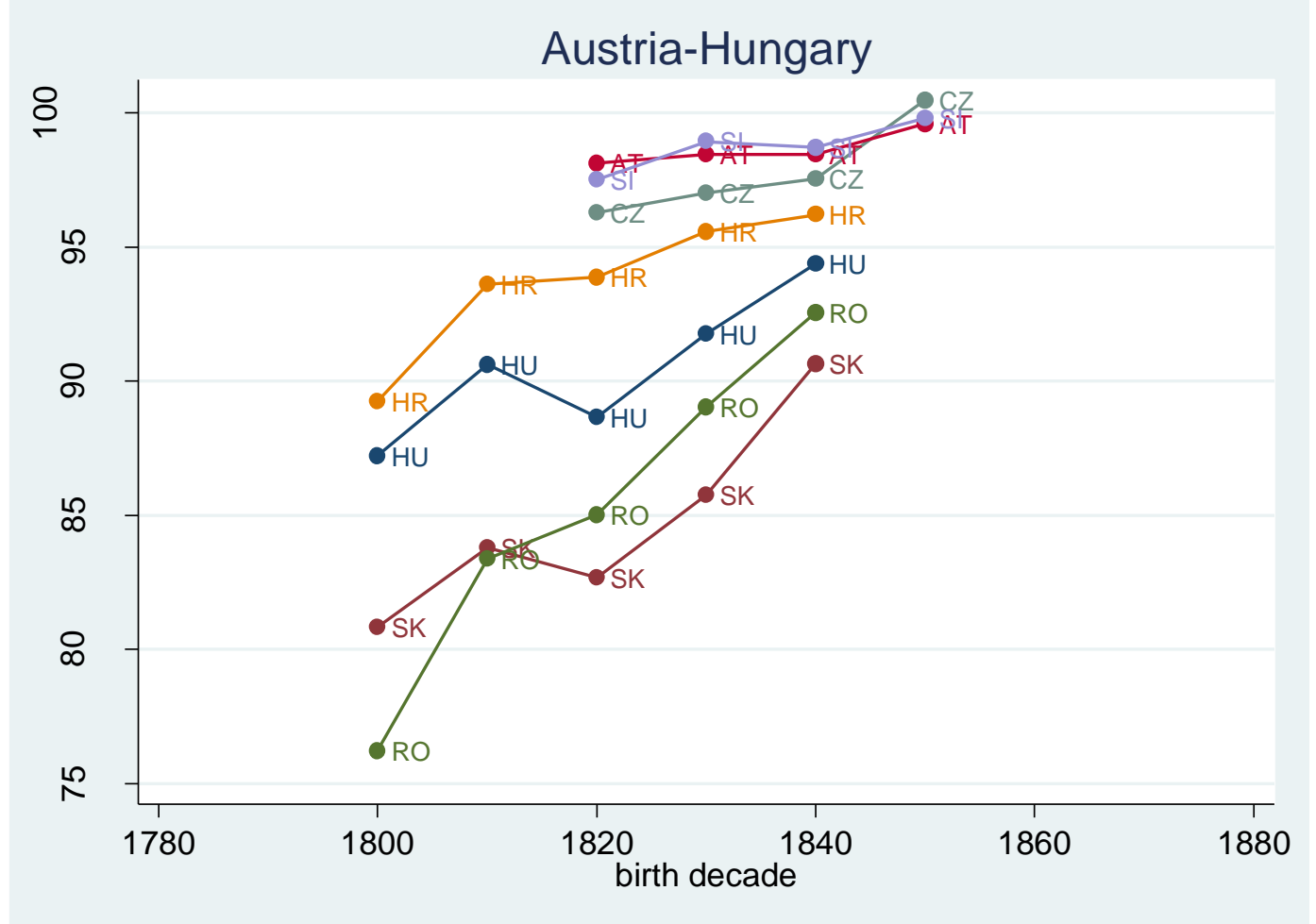

Figure 7 ABCC mean of the Western periphery

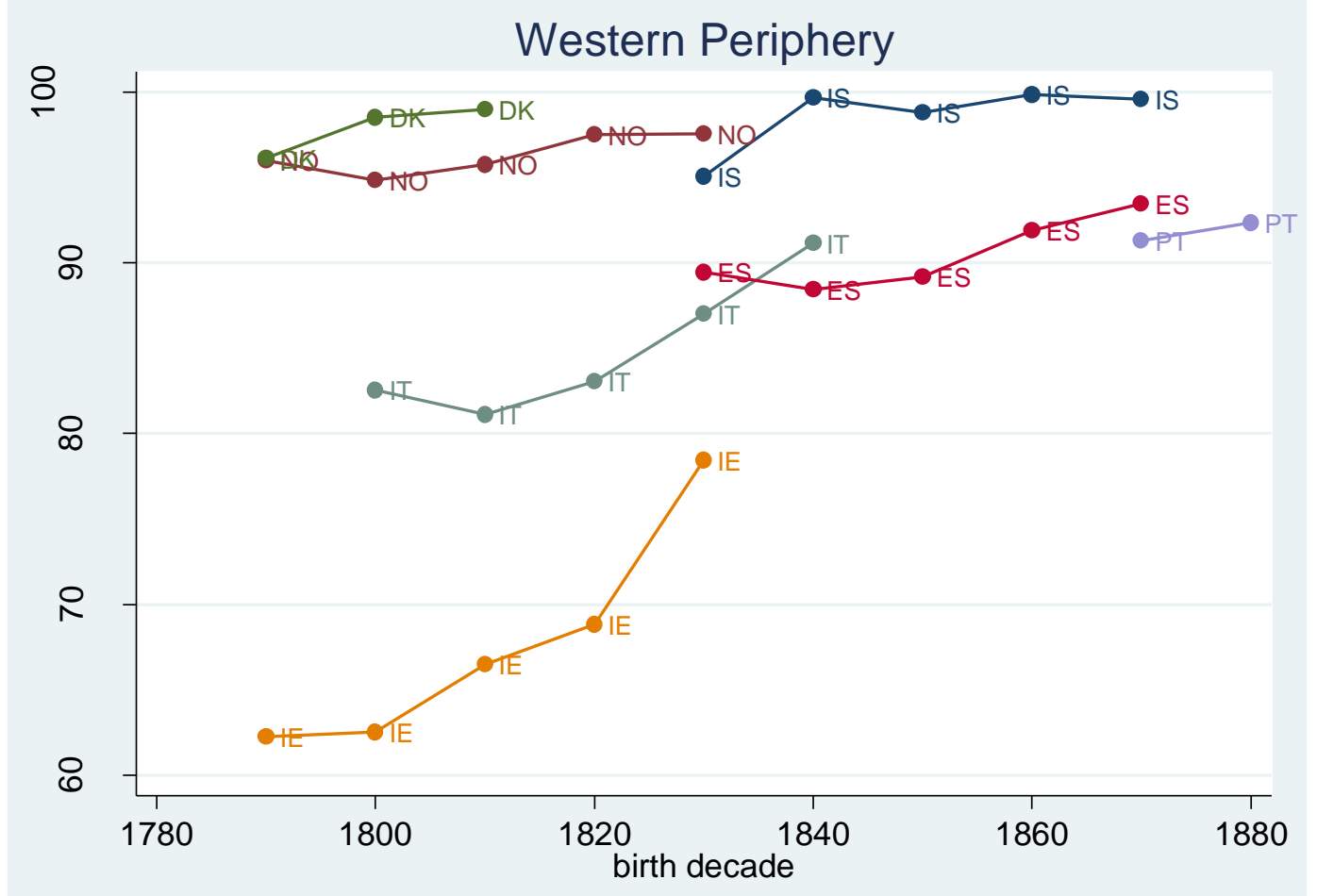


Figure 8 ABCC mean of East European countries

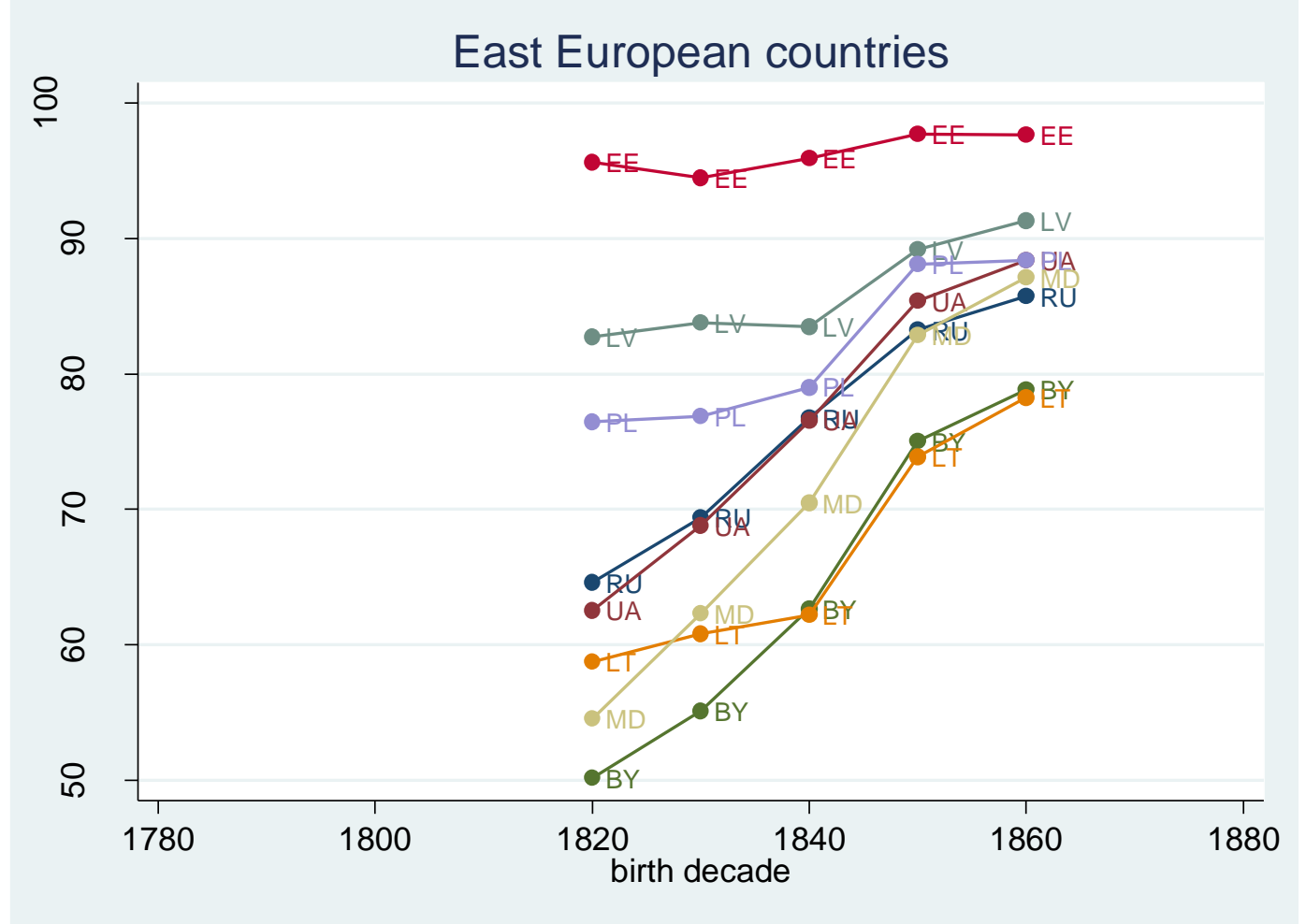

Figure 9 ABCC mean of South-East European countries

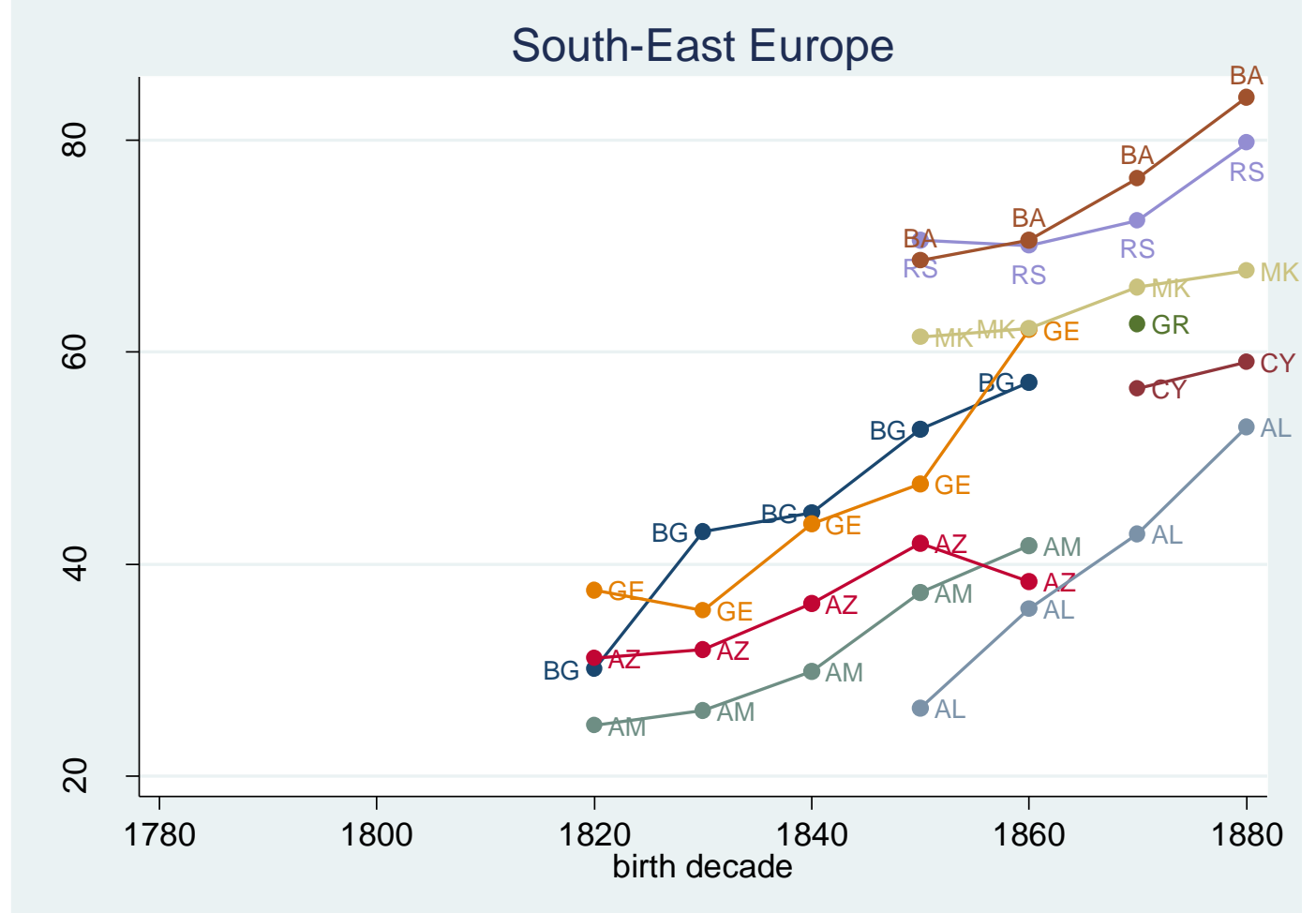


Figure 10 Regional ABCC differences in 1800

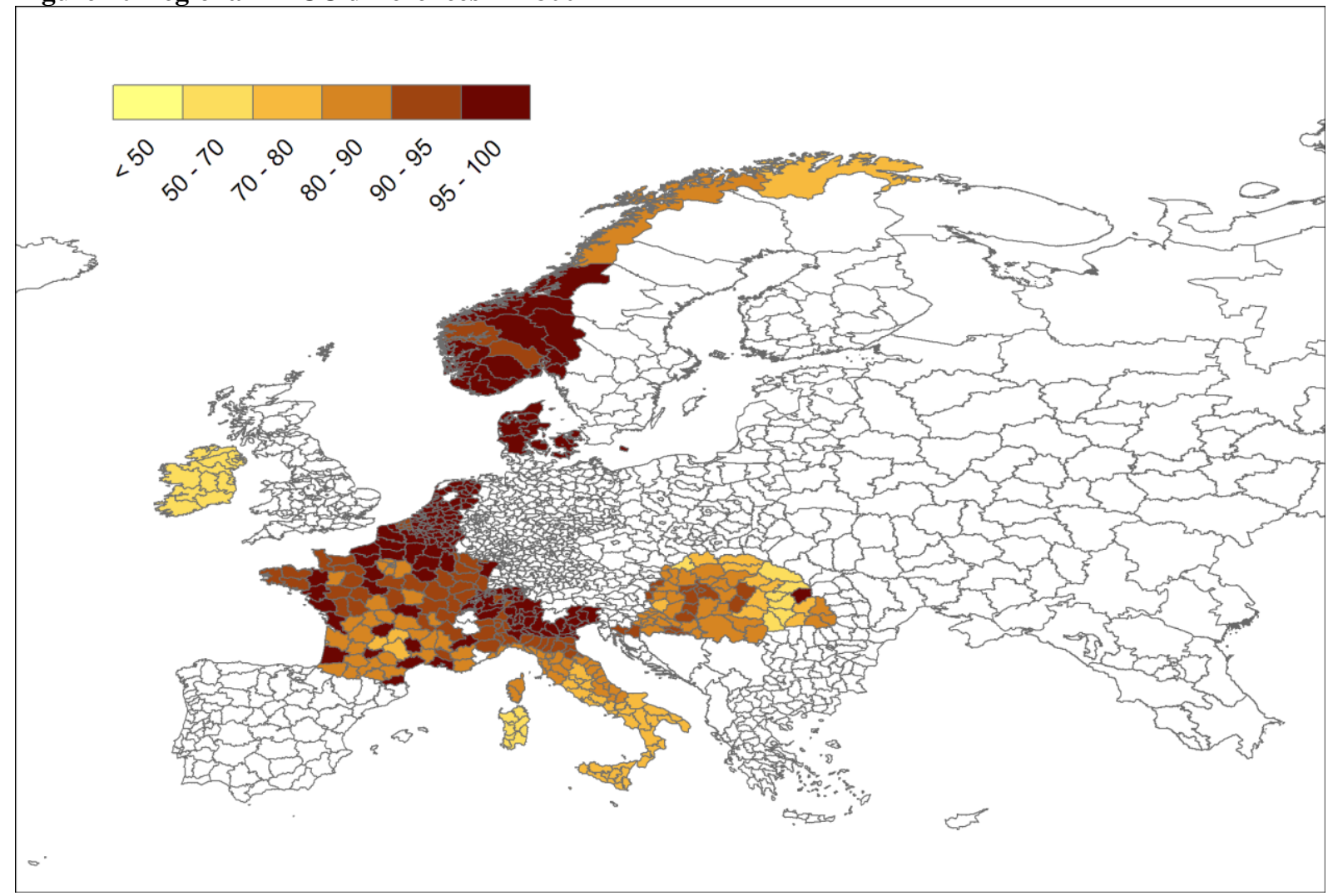

Figure 11 Regional ABCC differences in 1810 
Figure 12 Regional ABCC differences in 1820

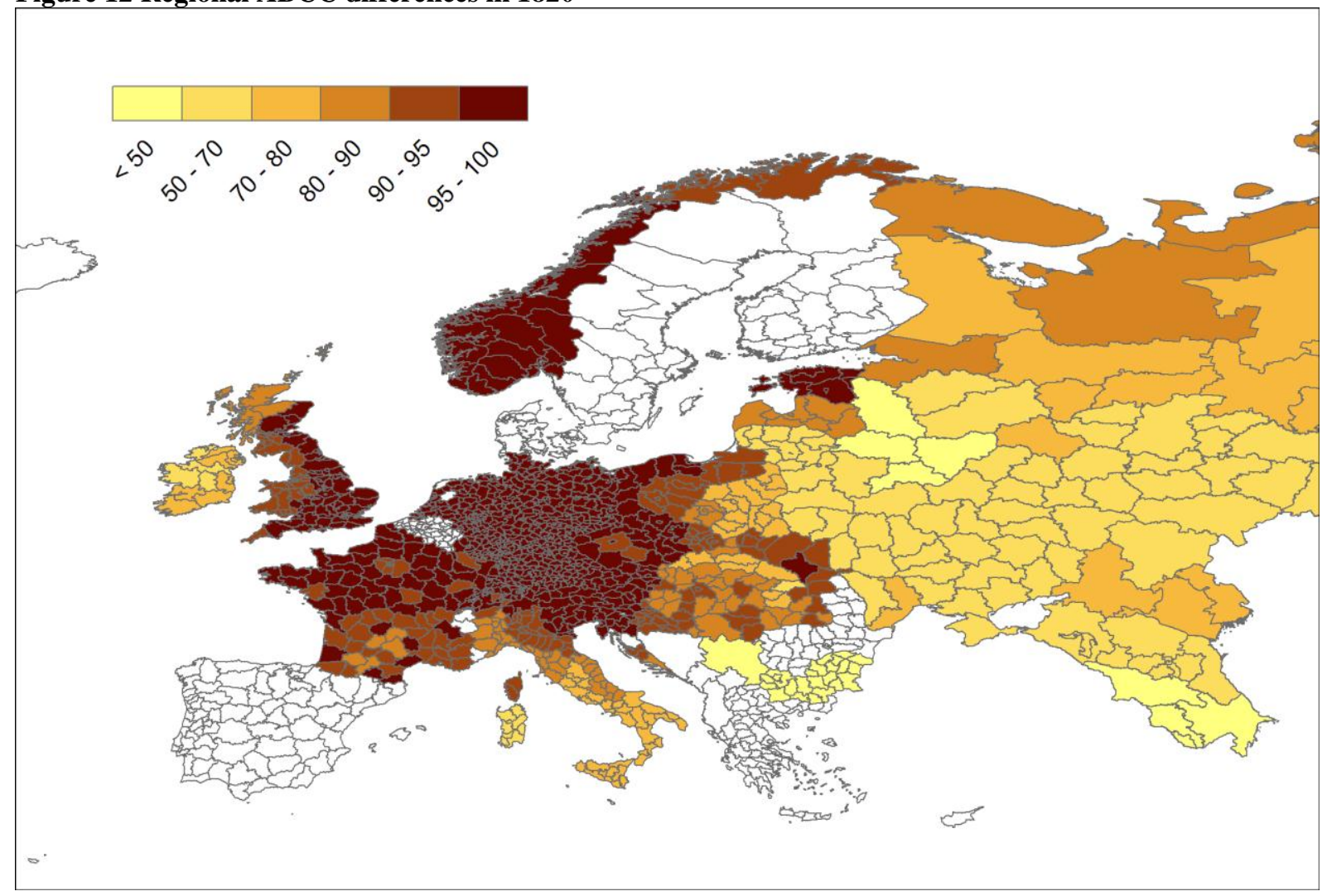

Figure 13 Regional ABCC differences in 1830

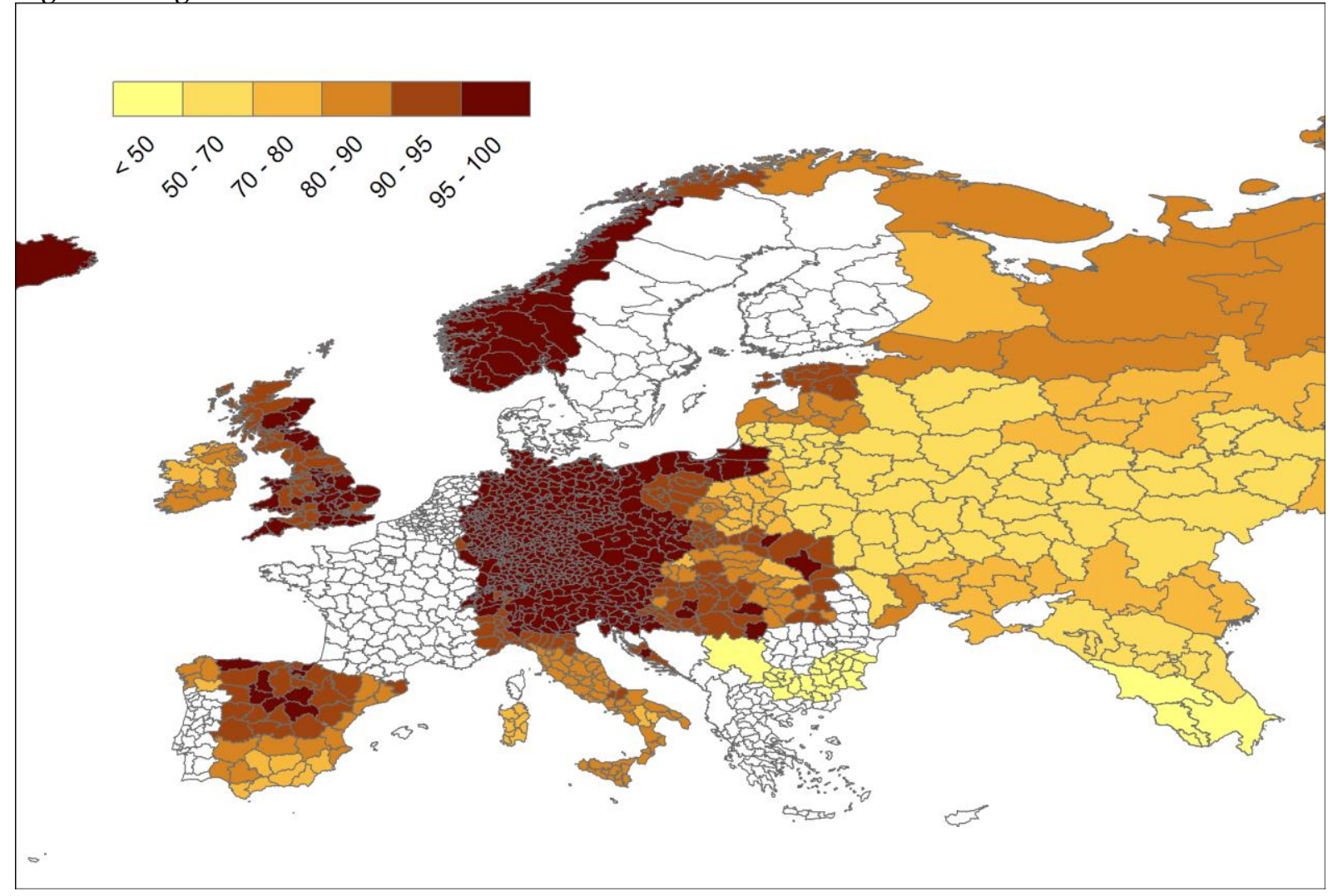


Figure 14 Regional ABCC differences in 1840

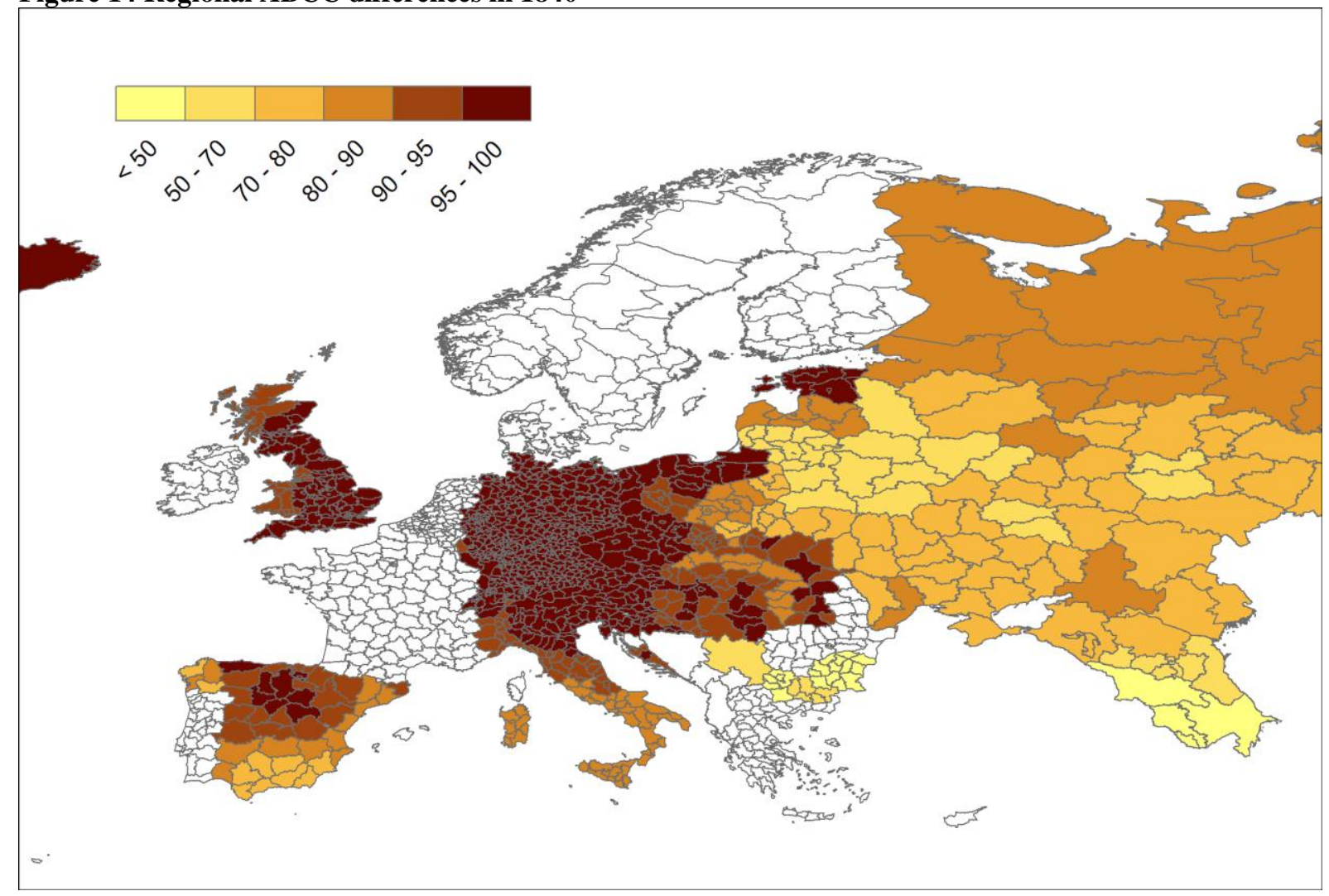

Figure 15 Regional ABCC differences in 1850

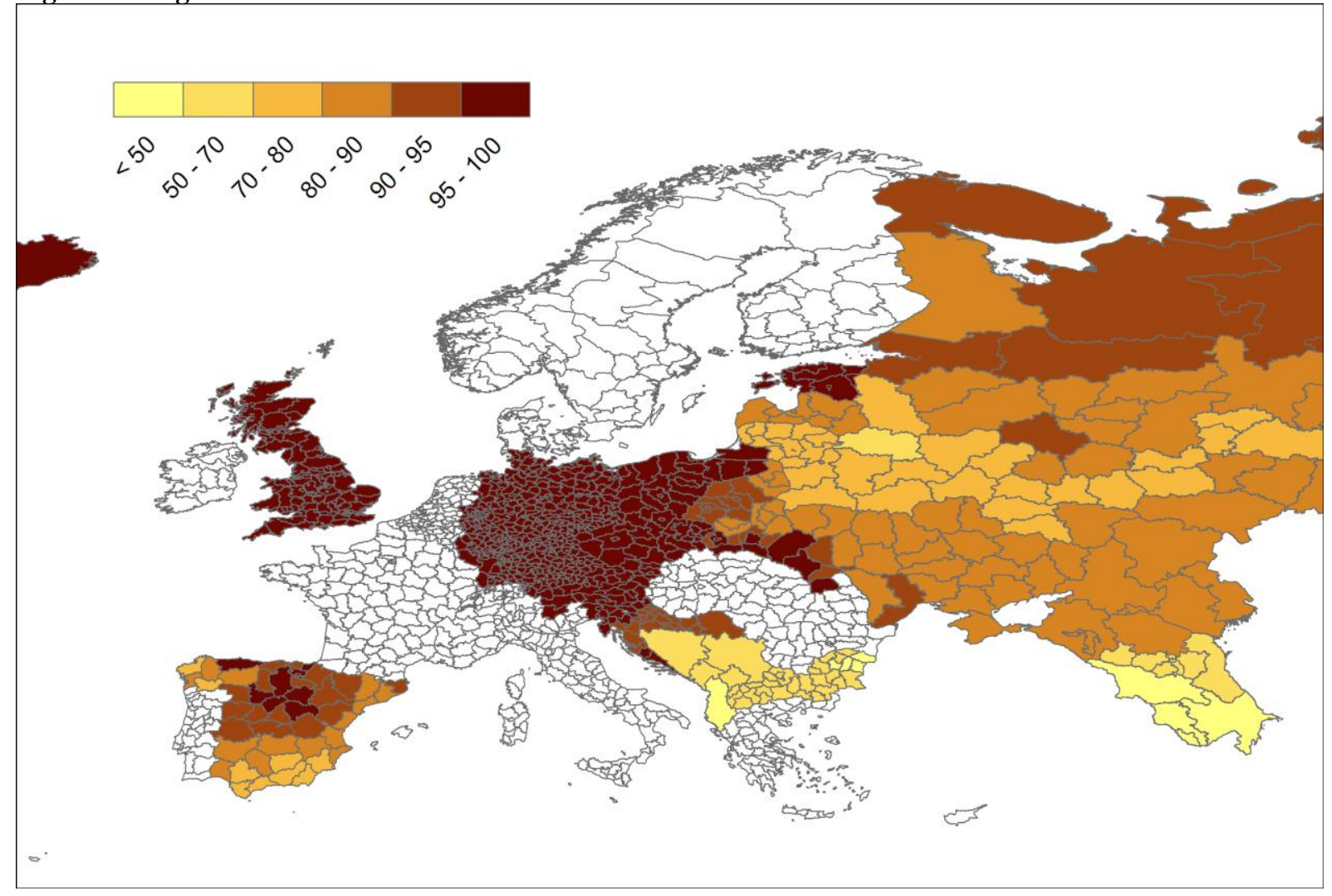


Figure 16 Regional ABCC differences in 1860

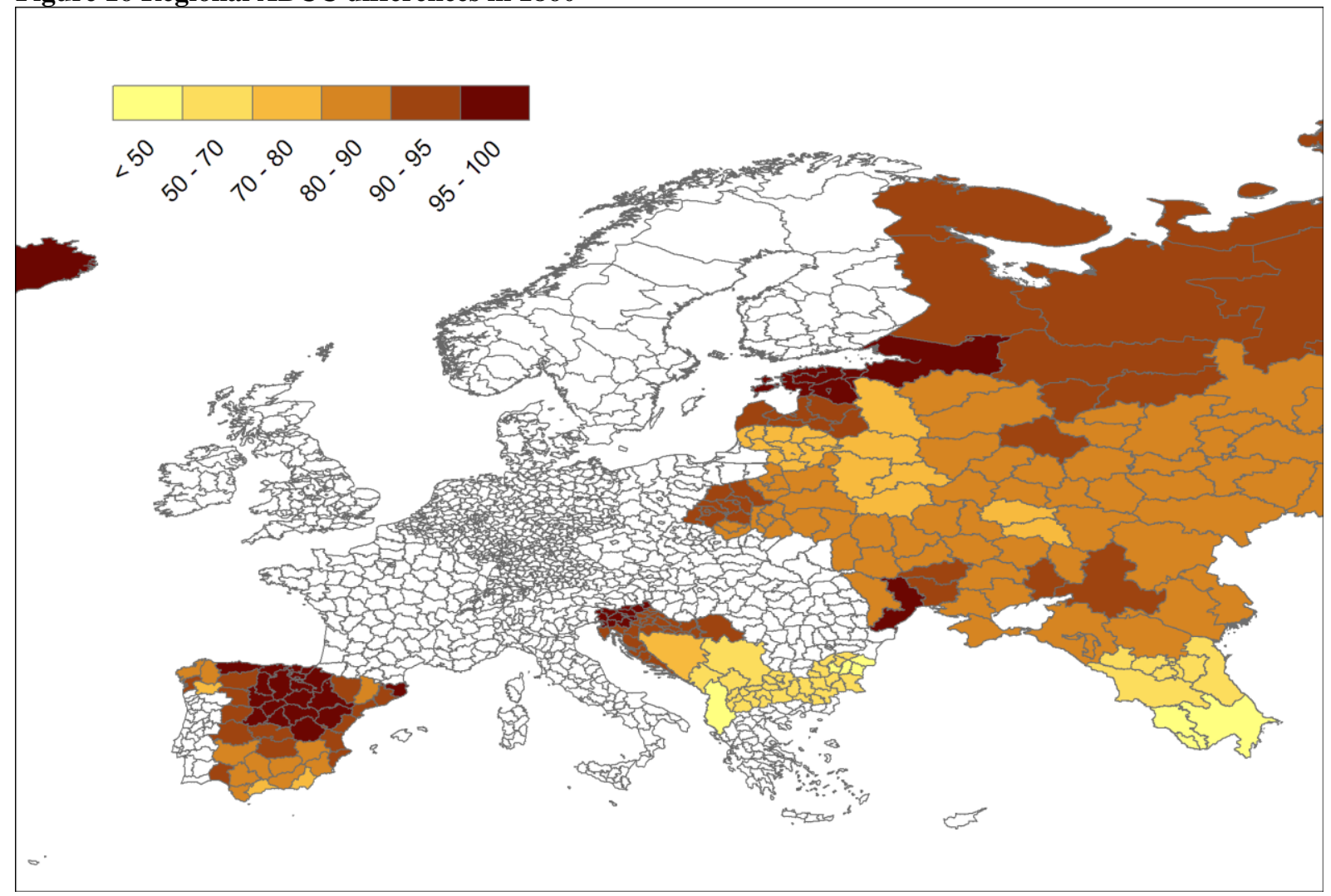

Figure 17 Regional ABCC differences in 1870

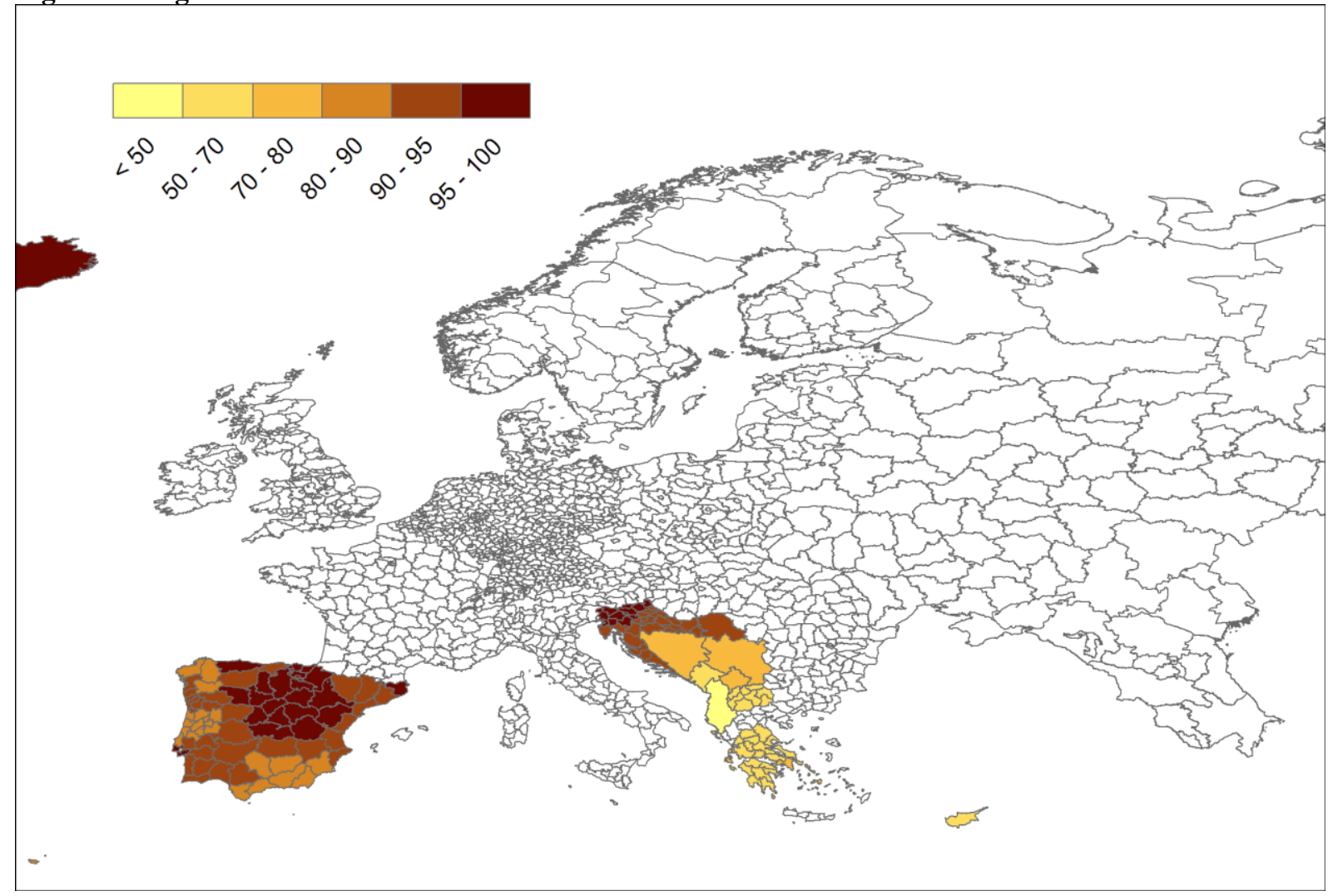


Figure 18 ABCC CV of the regions of Austria-Hungary

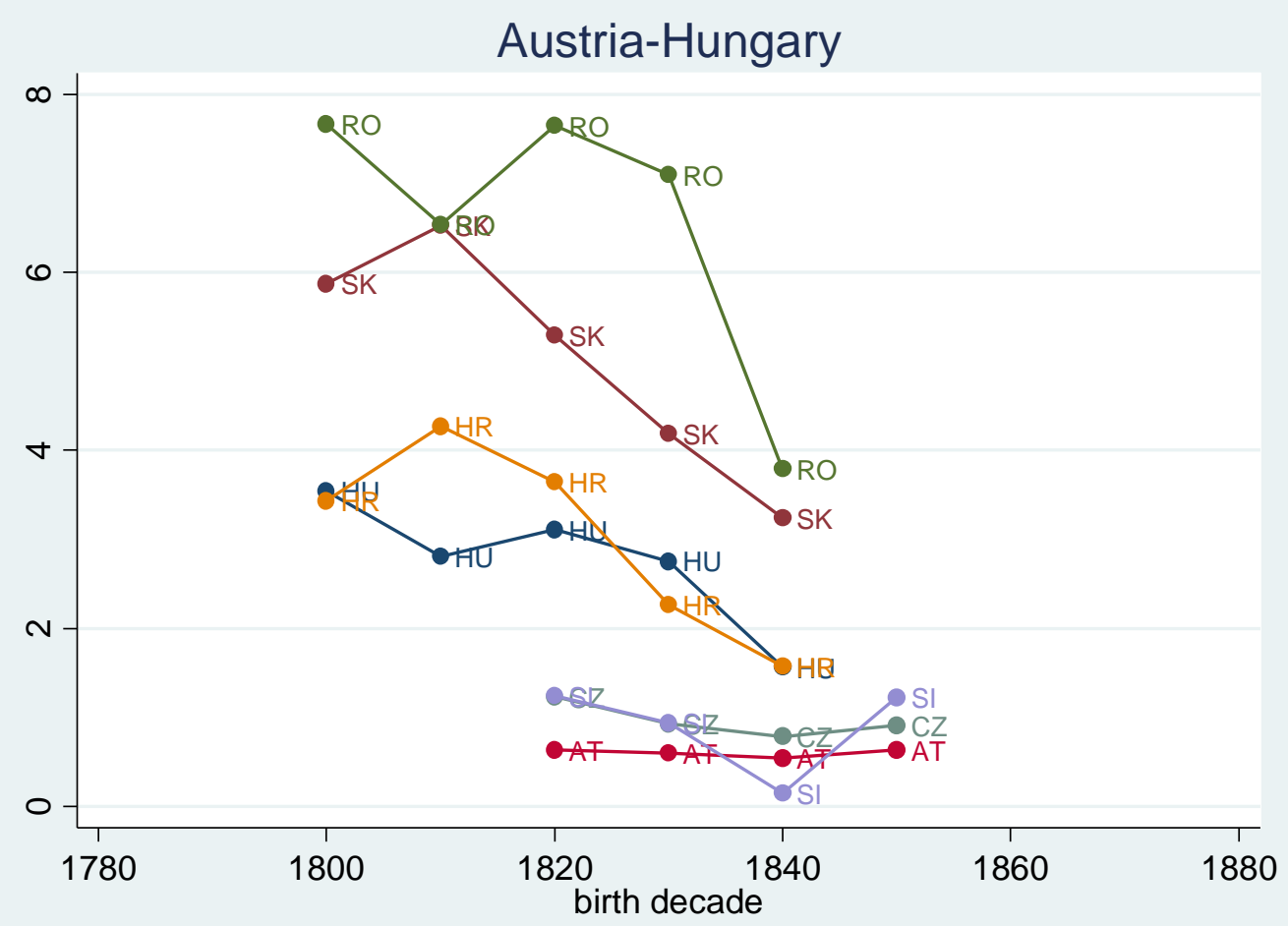

Figure 19 ABCC CV of the Western Periphery

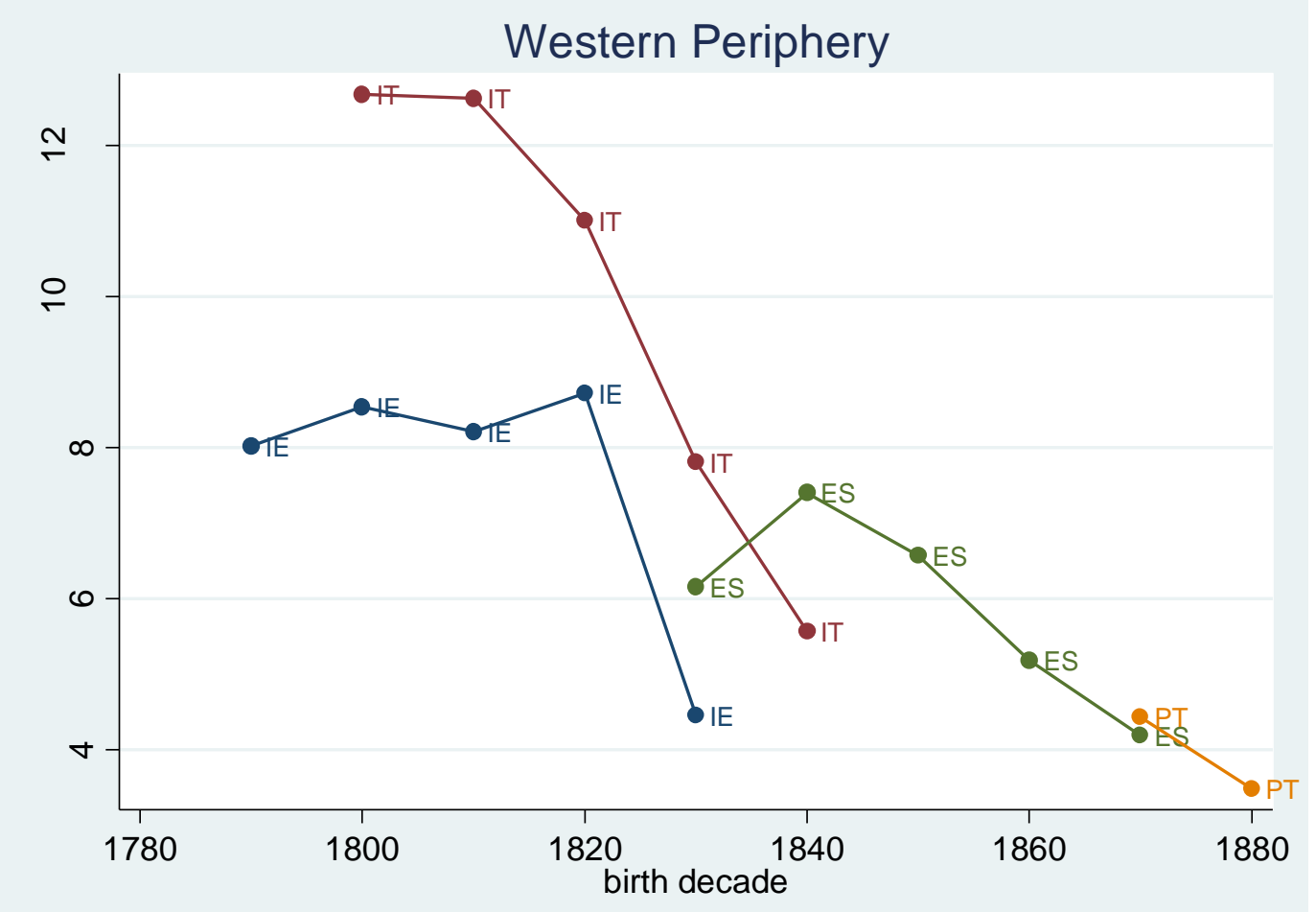


Figure 20 ABCC CV of East European countries

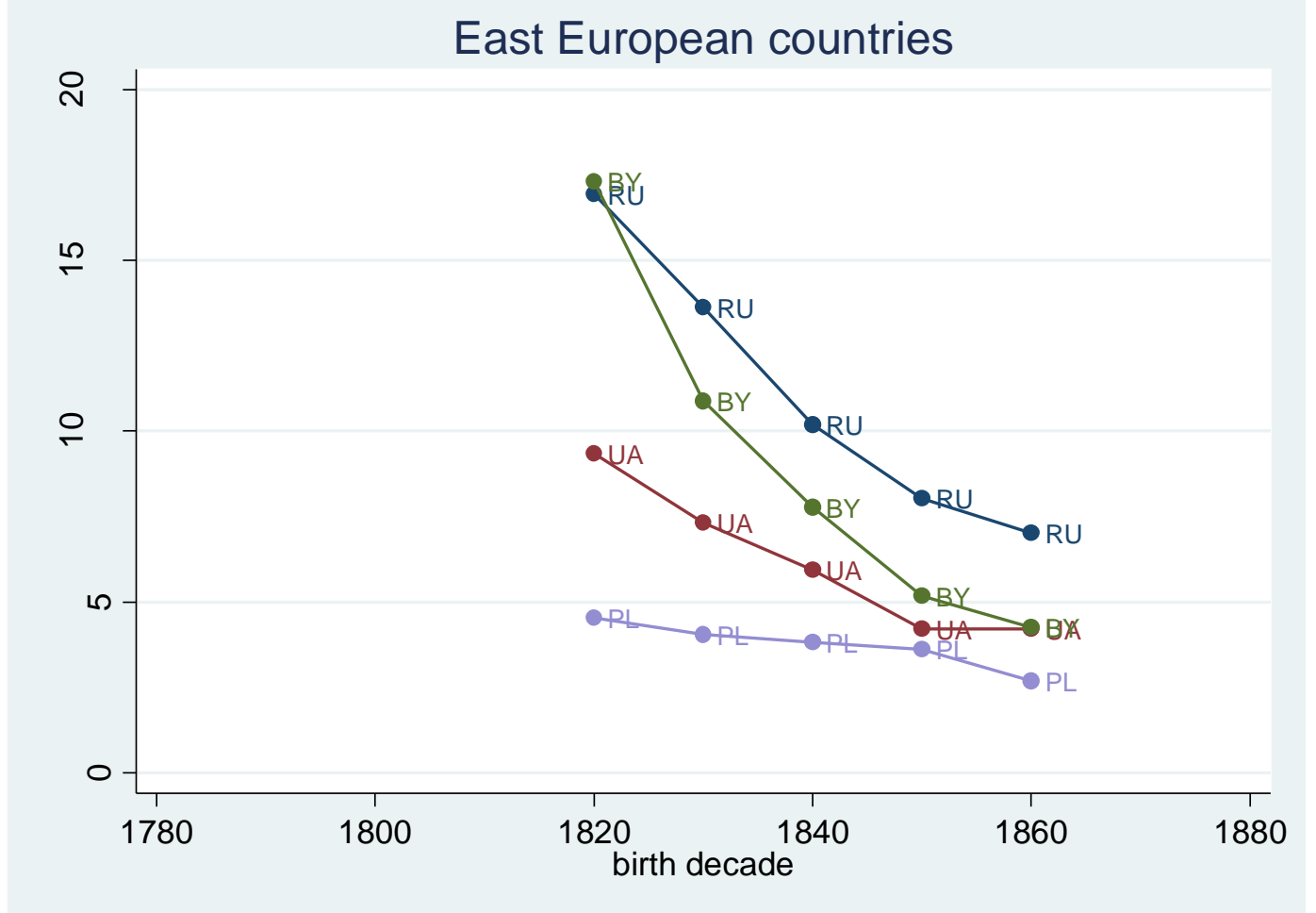

Figure 21 ABCC CV of South-East European countries

South-East Europe

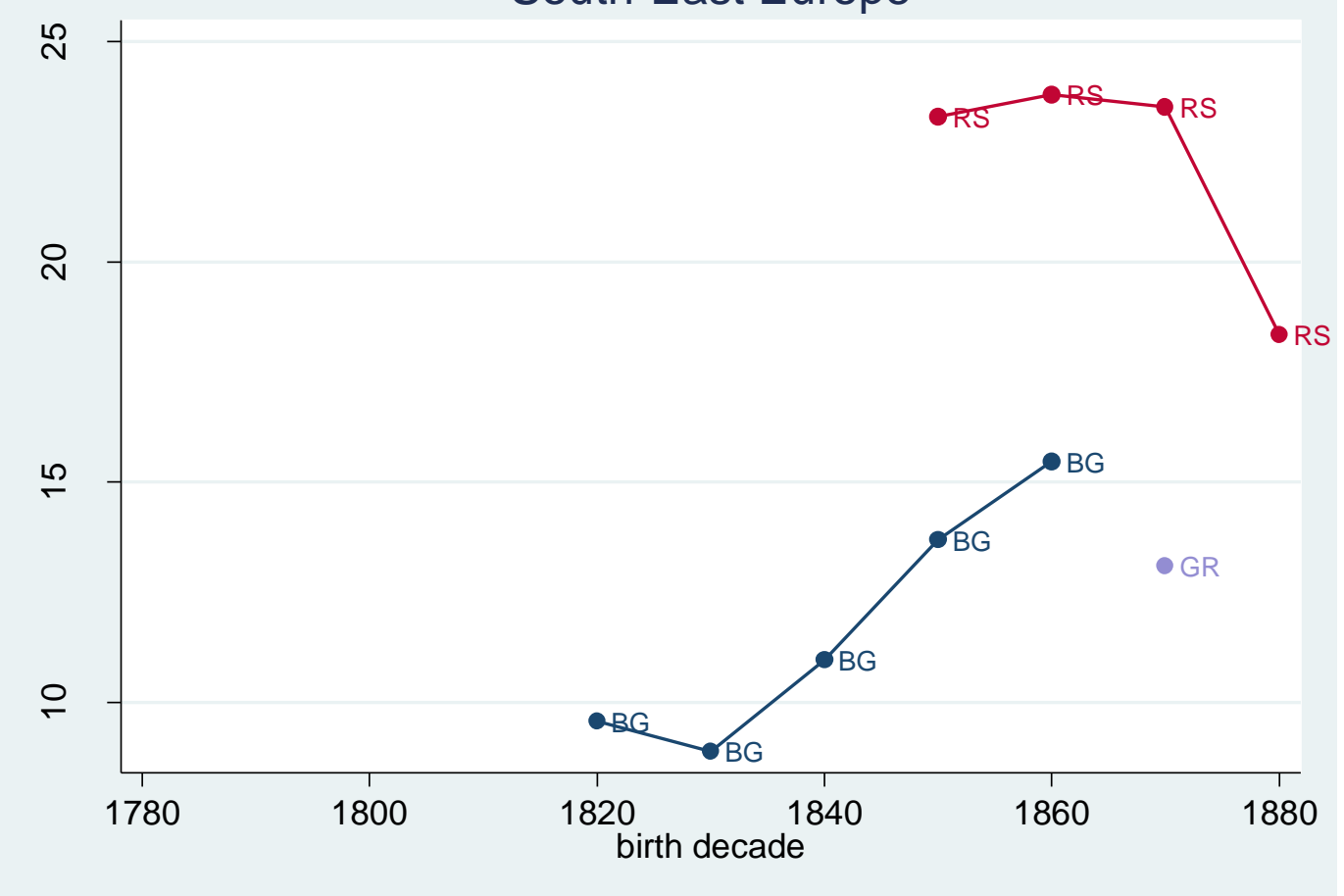




\section{WORKING PAPERS DE L'AFC}

\section{Année 2011}

WP2011-1 Amélie CHARLES, Olivier DARNÉ, Claude DIEBOLT

"A Revision of the US Business-Cycles Chronology 1790-1928"

WP2011-2 Cécile EDLINGER, Maxime MERLI, Antoine PARENT

"La diversification des portefeuilles français a la veille de 1914 ou l'image écornée du rentier français du 19e siècle"

WP2011-3 Jean-Luc DEMEULEMEESTER, Claude DIEBOLT

"Renouveler la science économique néo-classique ?

Prendre l'historicité au sérieux"

WP2011-4 Claude DIEBOLT, Karine PELLIER

"Measuring the 'Ideas': Evidence from a New International Patent Database"

WP2011-5 Cécile EDLINGER, Maxime MERLI, Antoine PARENT

"An optimal world portfolio on the eve of World War One:

Was there a bias to investing in the New World rather than in Europe?"

WP2011-6 Magali JAOUL-GRAMMARE

"L'évolution des inégalités dans l'enseignement supérieur universitaire français. L'influence des réformes institutionnelles et des ruptures économiques"

WP2011-7 Ralph HIPPE, Joerg BATEN

"Regional Inequality in Human Capital Formation in Europe, 1790-1880"

WP2011-8 Michel-Pierre CHELINI, Georges PRAT

"Cliométrie du chômage et des salaires en France, 1950-2008"

WP2011-9 Antoine PARENT

"Jadis et Naguère, la vision des crises financières dans l'histoire selon Reinhart et Rogoff"

WP2011-10 Claude DIEBOLT, Antoine PARENT, Jamel TRABELSI

"Comment la croissance américaine aurait-elle réagi à une politique monétaire expansionniste en 1929 ? Les enseignements cliométriques d'une simulation SVAR"

WP2011-11 Eric CHANCELLIER

"Henry L. Moore et le marché du coton, 1917: La météorologie agricole et le juste prix"

WP2011-12 Thi Hong Van HOANG

"La vie et la mort du marché de l'or à la Bourse de Paris de 1948 à 2004"
La liste complète des Working Papers est disponible sur le site www.cliometrie.org 